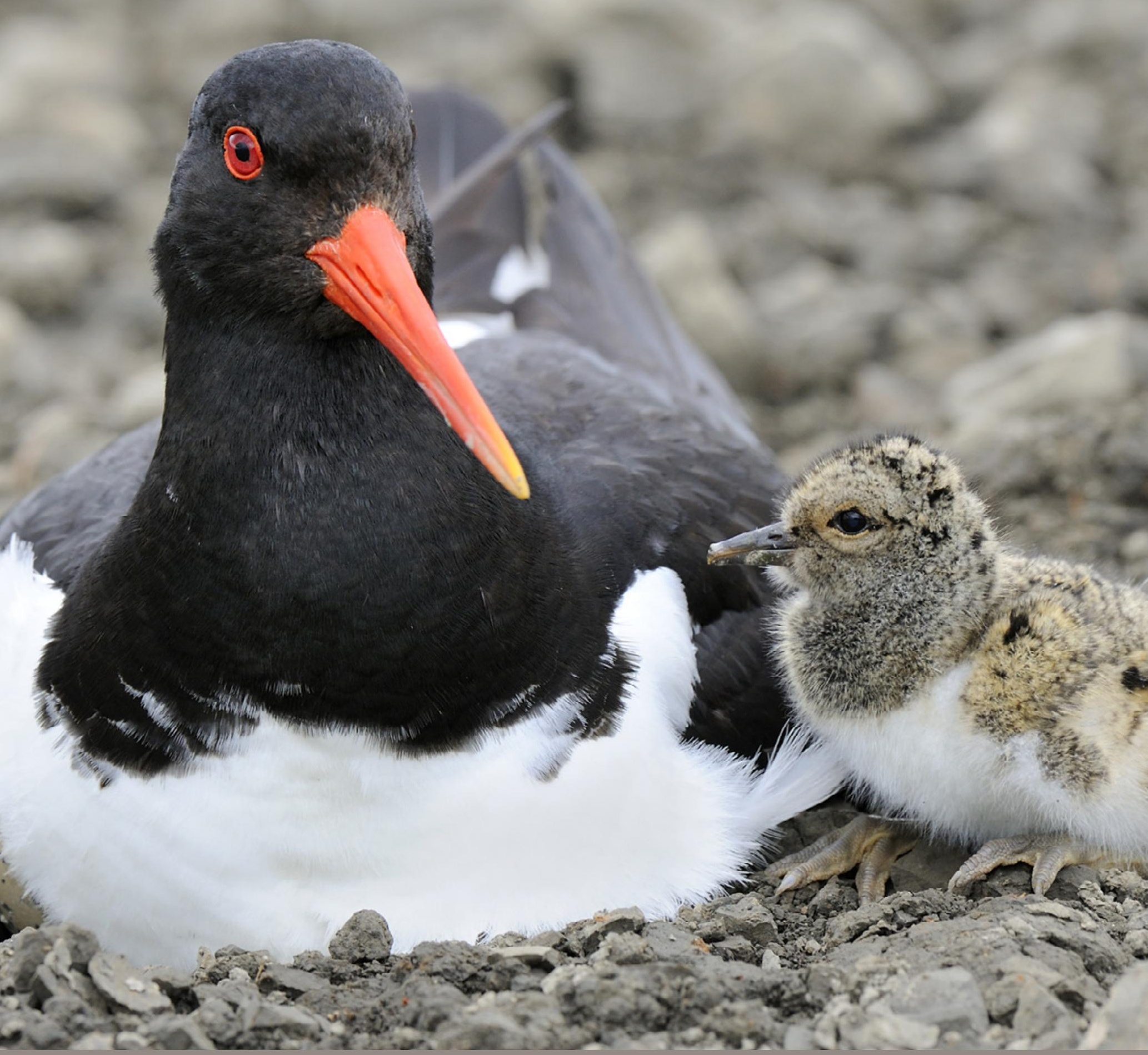

\title{
Broedsucces van kustbroedvogels in de Waddenzee in 2017
}



Broedsucces van kustbroedvogels in de Waddenzee in 2017 
Dit Technical report is gemaakt conform het Kwaliteitsmanagementsysteem (KMS) van de unit Wettelijke Onderzoekstaken Natuur \& Milieu, onderdeel van Wageningen University \& Research.

De WOT Natuur \& Milieu voert wettelijke onderzoekstaken uit op het beleidsterrein natuur en milieu. Deze taken worden uitgevoerd om een wettelijke verantwoordelijkheid van de Minister van Landbouw, Natuur en Voedselkwaliteit (LNV) te ondersteunen. We zorgen voor rapportages en data voor (inter)nationale verplichtingen op het gebied van agromilieu, biodiversiteit en bodeminformatie, en werken mee aan producten van het Planbureau voor de Leefomgeving zoals de Balans van de Leefomgeving.

\section{Disclaimer WOt-publicaties}

De reeks 'WOt-technical reports' bevat onderzoeksresultaten van projecten die kennisorganisaties voor de unit Wettelijke Onderzoekstaken Natuur \& Milieu hebben uitgevoerd.

WOt-technical report 136 is het resultaat van een onderzoeksopdracht van en gefinancierd door het ministerie van Landbouw, Natuur en Voedselkwaliteit (LNV). 


\section{Broedsucces van kustbroedvogels in de Waddenzee in 2017}

K. Koffijberg, J.S.M. Cremer, P. de Boer, J. Nienhuis, K. Oosterbeek \& J. Postma

Wettelijke Onderzoekstaken Natuur \& Milieu

Wageningen, december 2018

WOt-technical report 136

Sovon-rapport 2018/72

WMR-Rapport C089/18

ISSN 2352-2739

DOI: $10.18174 / 465991$ 


\title{
Referaat
}

Koffijberg K., J.S.M. Cremer, P. de Boer, J. Nienhuis, K. Oosterbeek \& J. Postma (2018). Broedsucces van kustbroedvogels in de Waddenzee in 2017. WOt-technical report 136; Sovon-rapport 2018/72; Wageningen Marine Research-rapport C089/18. WOT Natuur \& Milieu, WUR, Wageningen / Sovon Vogelonderzoek Nederland, Nijmegen / Wageningen Marine Research, Den Helder. 38 blz; 11 figs; 3 tab; 31 refs.

Sinds 2005 worden in de Waddenzee jaarlijks gegevens verzameld over het broedsucces van een aantal karakteristieke kustbroedvogels. Tien vogelsoorten worden gevolgd die representatief worden geacht voor specifieke habitats en voedselgroepen. Het reproductiemeetnet kustbroedvogels wordt uitgevoerd als een 'early warning systeem' om het reproducerend vermogen van de vogelpopulaties in de Waddenzee te volgen en de achterliggende processen van populatieveranderingen te doorgronden. Het fungeert als een belangrijke aanvulling op de monitoring van aantallen en aantalsveranderingen en wordt uitgevoerd in het kader van trilaterale afspraken met Duitsland en Denemarken (TMAP). Tevens worden de gegevens opgenomen in de biodiversiteitsindicator B3 van OSPAR, t.b.v. de Kaderrichtlijn Marien. Uit de resultaten van 2017 blijkt dat er ten opzichte van de voorgaande jaren weinig verbetering in het broedsucces is opgetreden, en de meeste soorten, Scholekster, Kluut en Noordse Stern voorop, veel te weinig jongen grootbrengen om een stabiele populatie te waarborgen.

Trefwoorden: broedsucces, Waddenzee, Trilaterale monitoring, TMAP, Lepelaar, Eider, Scholekster, Kluut, Kokmeeuw, Kleine Mantelmeeuw, Zilvermeeuw, Grote Stern, Visdief, Noordse Stern

\begin{abstract}
Koffijberg K., J.S.M. Cremer, P. de Boer, J. Nienhuis, K. Oosterbeek \& J. Postma (2018). Breeding success of coastal breeding birds in the Wadden Sea in 2017. WOt technical report 136; Sovon report 2018/72; WMR report C089/18. Statutory Research Tasks Unit for Nature \& the Environment, WUR, Wageningen / Sovon Vogelonderzoek Nederland, Nijmegen / Wageningen Marine Research, Den Helder. 38 p., 11 figs; 3 tabs; 31 refs.

Data have been collected on the breeding success of several characteristic coastal breeding birds in the Wadden Sea each year since 2005. Ten birds species considered representative of specific habitats and food groups are being monitored. The monitoring scheme on breeding success in coastal breeding birds is run as an 'early warning system' to follow the reproductive capacity of the bird populations in the Wadden Sea and understand the processes underlying fluctuations in populations. It is a valuable addition to the monitoring of population numbers and is carried out under a trilateral agreement with Germany and Denmark (TMAP). The data are also included in the OSPAR biodiversity indicator B3 under the Marine Strategy Framework Directive. The 2017 results indicate that there has been little improvement in breeding success compared with previous years and that most species, especially Eurasian Oystercatcher, Pied Avocet and Arctic Tern, raised far too few young to maintain a stable population.
\end{abstract}

Keywords: breeding success, Wadden Sea, trilateral monitoring, TMAP, Eurasian Spoonbill, Common Eider, Eurasian Oystercatcher, Pied Avocet, Black-headed Gull, Lesser Black-backed Gull, Herring Gull, Sandwich Tern, Common Tern, Arctic Tern

Auteurs: Kees Koffijberg (Sovon Vogelonderzoek Nederland), Jenny Cremer (Wageningen Marine Research), Peter de Boer, Jeroen Nienhuis, Kees Oosterbeek \& Jelle Postma (allen Sovon Vogelonderzoek Nederland)

Foto omslag: Silvan Puijman

\section{(C) 2018 SOVON Vogelonderzoek Nederland}

Postbus 6521, 6503 GA Nijmegen

Tel. (024) 7410 410; e-mail:

kees.koffijberg@sovon.nl; www.sovon.nl
Wageningen Marine Research

Postbus 57, 1780 AB Den Helder

Tel. (0317) 480 900; e-mail: jenny.cremer@wur.nl

De reeks WOt-technical reports is een uitgave van de unit Wettelijke Onderzoekstaken Natuur \& Milieu, onderdeel van Wageningen University \& Research. Dit technical report is verkrijgbaar bij het secretariaat. De publicatie is ook te downloaden via www.wur.nl/wotnatuurenmilieu.

Wettelijke Onderzoekstaken Natuur \& Milieu, Postbus 47, 6700 AA Wageningen

Tel: (0317) 4854 71; e-mail: info.wnm@wur.nl; Internet: www.wur.nl/wotnatuurenmilieu.

Alle rechten voorbehouden. Niets uit deze uitgave mag worden verveelvoudigd en/of openbaar gemaakt door middel van druk, fotokopie, microfilm of op welke andere wijze ook zonder voorafgaande schriftelijke toestemming van de uitgever. De uitgever aanvaardt geen aansprakelijkheid voor eventuele schade voortvloeiend uit het gebruik van de resultaten van dit onderzoek of de toepassing van de adviezen. 


\section{Woord vooraf}

In het voorliggende WOt-technical report worden de resultaten van het reproductiemeetnet kustbroedvogels in 2017 gepubliceerd. Doel is om de verzamelde gegevens te presenteren en toegankelijk te maken voor breder gebruik. Het project 'Reproductiemeetnet Kustbroedvogels' wordt uitgevoerd in het kader van de wettelijke onderzoekstaken binnen het thema Informatievoorziening Natuur, gecoördineerd door het ministerie van Landbouw, Natuur en Voedselkwaliteit, en is onderdeel van het trilaterale monitoring programma TMAP. Het hiervoor benodigde veldwerk wordt gecoördineerd door Sovon Vogelonderzoek Nederland, in samenwerking met Wageningen Marine Research. Het onderzoek zou zonder de inzet van veel vrijwilligers van Sovon niet kunnen worden uitgevoerd.

Kees Koffijberg, Jenny Cremer, Peter de Boer, Jeroen Nienhuis, Kees Oosterbeek en Jelle Postma 



\section{Inhoud}

Woord vooraf

Summary

$1 \quad$ Inleiding

2 Methode en materiaal

2.1 Opzet van het Meetnet Reproductie in de Waddenzee $\quad 15$

2.2 Meetinspanning $2017 \quad 16$

$\begin{array}{lll}2.3 & \text { Verwerking van de gegevens } & 18\end{array}$

2.4 Analyses en presentatie gegevens $\quad 18$

$\begin{array}{ll}2.5 & \text { Bijzondere omstandigheden in } 2017 \\ \end{array}$

$\begin{array}{llr}3 & \text { Resultaten } & \mathbf{2 1}\end{array}$

$\begin{array}{lll}3.1 & \text { Algemeen } & 21\end{array}$

\begin{tabular}{ll}
3.2 & Lepelaar Platalea leucorodia - Eurasian Spoonbill \\
\hline
\end{tabular}

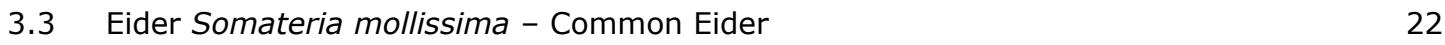

3.4 Scholekster Haematopus ostralegus - Eurasian Oystercatcher 23

3.5 Kluut Recurvirostra avosetta - Pied Avocet $\quad 24$

3.6 Kokmeeuw Chroicocephalus ridibundus - Black-headed Gull 24

3.7 Kleine Mantelmeeuw Larus fuscus - Lesser Black-backed Gull 25

3.8 Zilvermeeuw Larus argentatus - Herring Gull 26

\begin{tabular}{ll}
3.9 & Grote Stern Sterna sandvicensis - Sandwich Tern \\
\hline
\end{tabular}

\begin{tabular}{ll}
3.10 & Visdief Sterna hirundo - Common Tern \\
\hline .11 & 27
\end{tabular}

\begin{tabular}{lr}
3.11 & Noordse Stern Sterna paradisaea - Arctic Tern \\
\hline
\end{tabular}

$4 \quad$ Conclusies en discussie $\quad 31$

$\begin{array}{ll}\text { Literatuur } & 33\end{array}$

$\begin{array}{ll}\text { Verantwoording en dankwoord } & 35\end{array}$ 



\section{Samenvatting}

In 2017 zijn in de Nederlandse Waddenzee voor het $13^{\mathrm{e}}$ achtereenvolgende jaar op gecoördineerde wijze gegevens over het broedsucces van een selectie van kustbroedvogels verzameld. Momenteel gaat het om tien verschillende soorten, die zowel in de Nederlandse Waddenzee als in de Duitse en Deense Waddenzee worden gevolgd (Trilateral Monitoring and Assessment Program, TMAP). Deze soorten zijn Lepelaar, Eider, Scholekster, Kluut, Kokmeeuw, Kleine Mantelmeeuw, Zilvermeeuw, Grote Stern, Visdief en Noordse Stern. Het Meetnet Reproductie in het Nederlandse deel van de Waddenzee is onderdeel van de Wettelijke Onderzoekstaken Natuur \& Milieu voor het thema Informatievoorziening Natuur en wordt gecoördineerd door Sovon Vogelonderzoek Nederland in samenwerking met Wageningen Marine Research (WMR). Belangrijkste doel is het verzamelen van informatie over het broedsucces van kustbroedvogels, om daarmee zowel de 'gezondheidstoestand' van vogelpopulaties in de Waddenzee in kaart te brengen, als de mogelijkheid te hebben vooruit te kijken naar toekomstige populatieontwikkelingen. De meetinspanning in 2017 is gedragen door vrijwilligers, medewerkers van terreinbeheerders, medewerkers van verschillende instituten en medewerkers van Sovon. Er waren 76 broedlocaties verspreid over de Waddenzee waar informatie werd verzameld over het nestsucces (aantal succesvol uitgekomen legsels) en/of het uiteindelijke aantal vliegvlugge jongen per paar (hier verder broedsucces genoemd).

De resultaten in 2017 bevestigen in grote lijn de resultaten van voorgaande jaren en trends in het broedsucces in het afgelopen decennium zoals die in de rapportage over 2015-2016 werden gepresenteerd. De meeste soorten (Lepelaar uitgezonderd) brengen structureel te weinig jongen groot om de populatie op z'n minst stabiel te houden. Vooral Scholekster, Kluut en Noordse Stern doen het slecht. Van de soorten die ook in de nestfase worden gevolgd valt het lage nestsucces bij Eider, Scholekster, Kluut, Visdief en Noordse Stern op. Oorzaken voor het mislukken van nesten waren vaak predatie en hoge vloeden, waardoor nesten wegspoelden. Vooral de periode met regen en lage temperaturen, gepaard gaand met een zomerstorm op 6-7 juni, speelde veel broedvogels parten. Elektrische rasters kunnen helpen om het predatierisico te verlagen, zoals bij meeuwen en sternkolonies bij Oterdum in de Haven van Delfzijl of op de Punt van Reide. Echter, bij de Kluten in de Klutenplas in Noord-Groningen bleek zo'n raster niet te werken (alle nesten gepredeerd). Zijn nesten succesvol, dan is dat lang niet altijd een garantie dat ook veel kuikens uitvliegen. Kokmeeuwen en Visdieven in de tegen predatie beschermde kolonies in de Haven van Delfzijl en op de Punt van Reide bleken hier andermaal in het voordeel en hadden goede broedresultaten. De oorzaken voor het lage broedsucces zijn lang niet altijd goed te kwantificeren, vooral als er problemen in de voedselvoorziening spelen.

De aanhoudend slechte broedresultaten werken door in de aantalsontwikkeling van broedvogels in de Waddenzee. Van de tien soorten zijn er zeven die tussen 1990 en 2017 een afname laten zien, zoals blijkt uit de gegevens van het Meetnet Broedvogels. Alleen Lepelaar, Kleine Mantelmeeuw en Grote Stern delen niet in de negatieve trend. De resultaten zoals die in het Meetnet Reproductie in 2017 zijn verzameld geven weinig aanknopingspunten voor een trendbreuk en een spoedig herstel van de aantallen kustbroedvogels in de Waddenzee. 



\section{Summary}

This report present the results of the monitoring of breeding success of a selection of coastal breeding birds in the Dutch Wadden Sea in 2017. This monitoring is carried out as part of a national monitoring scheme and the trilateral TMAP programme in the Dutch, German and Danish Wadden Sea. It includes a selection of ten coastal breeding birds, at present Eurasian Spoonbill, Common Eider, Eurasian Oystercatcher, Pied Avocet, Black-headed Gull, Herring Gull, Lesser Black-backed Gull, Sandwich Tern, Common Tern and Arctic Tern. Data are collected both during the nesting phase (referred to as nest success) and during the chick-rearing phase (referred to as breeding success). The main aim is to determine breeding success in terms of the number of fledged chicks per pair. Data collection in 2017 was carried out at 76 sites (a site is defined as a combination of species and site) (see Figure 2.1).

The results obtained in 2017 confirm the poor reproductive output in many species observed in previous years. Apart from Eurasian Spoonbill, all species raised too few offspring to maintain at least a stable population. Eurasian Oystercatcher, Pied Avocet and Artic Tern in particular seem to perform poorly. For those species for which the fate of nests was monitored, nest success was low in Common Eider, Eurasian Oystercatcher, Pied Avocet, Common Tern and Arctic Tern. The most frequently reported causes of failure were predation and storm tides (notably a rainy period, low temperatures and stormy weather on 6-7 June). A few colonies of Common Tern and Black-headed Gull that were protected by electric fences yielded a higher nest success (and also final breeding success), but a similarly treated colony of Pied Avocet was raided by predators, despite the fence. In addition to the low nest success, most species also produce too few fledged chicks.

Out of the 10 species included in the breeding success monitoring scheme, 7 have experienced declining numbers since the start of coordinated breeding bird counts in 1990. Exceptions are the Eurasian Spoonbill, Lesser Black-backed Gull and Sandwich Tern. In the first two species, earlier population growth has now levelled off. The Sandwich Tern is currently redistributing its main colonies away from its former stronghold on the island of Griend to inland colonies on the island of Texel and a small saltmarsh area on the island of Ameland. The low reproduction rates recorded in most breeding bird species are expected to be a main driver for further declines, but to understand the full demographic process causing populations to decline these rates should also be viewed in the context of data on annual survival. 



\section{$1 \quad$ Inleiding}

Naast de monitoring van aantallen en verspreiding van kustbroedvogels (Koffijberg et al. 2015a, Boele et al. 2018) worden in de Nederlandse Waddenzee sinds 2004-2005 (soms al langer) gegevens verzameld over het broedsucces van kustbroedvogels. Deze monitoring van broedsucces vindt plaats in het kader van het Wettelijke Onderzoekstaken Natuur \& Milieu voor het thema Informatievoorziening Natuur en (sinds 2010) voor het trilaterale TMAP-programma (Thorup \& Koffijberg 2015). De broedsuccesgegevens van de Waddenzee zijn verder onderdeel van de biodiversiteitsindicatoren voor de Kaderrichtlijn Marien (https://oap.ospar.org/en/ospar-assessments/intermediate-assessment2017/). Uitvoering van het meetnet is in handen van Wageningen Marine Research (WMR) en Sovon Vogelonderzoek Nederland.

Het broedsucces is naast de jaarlijkse overleving één van de belangrijkste parameters die de demografie van kustbroedvogels in de Waddenzee beschrijft (Van der Jeugd et al. 2014). Omdat we bij kustbroedvogels doorgaans met langlevende soorten te maken hebben, geeft de monitoring van broedsucces een belangrijk signaal in welke toestand de betreffende soorten zich bevinden. Kennis over de jaarlijkse variatie in broedresultaten is dus van belang als een early warning systeem om het reproducerend vermogen van de vogelpopulaties in de Waddenzee te volgen, analoog aan het principe van het 'toekomstperspectief' zoals dat in de Vogelrichtlijn wordt verwoord (CBS 2013). Informatie over broedsucces geeft inzicht in de achtergronden voor aantalsveranderingen en een snellere indicatie waar eventueel beleidsmaatregelen zijn te nemen om een (verwachte) negatieve aantalstrend een halt toe te roepen.

De concrete doelstellingen die bij de opzet van het meetnet zijn geformuleerd, luiden:

- vaststellen van het reproducerend vermogen van broedvogelpopulaties in de Waddenzee;

- jaarlijkse monitoring van het broedsucces bij een selectie van soorten in representatieve steekproefgebieden verspreid over de Waddenzee.

Er worden tien soorten broedvogels gevolgd (zie tabel 2.2), ieder representatief geacht voor een bepaalde voedselgroep. Deze selectie is bepaald in trilateraal overleg met TMAP-vertegenwoordigers uit Duitsland en Denemarken. Deze selectie wordt vanaf 2010 gemonitord. Een aantal soorten in de selectie worden in de Nederlandse Waddenzee al vanaf 2004-2005 (soms langer) gevolgd.

De resultaten tot nu toe hebben laten zien dat veel broedvogels in de Nederlandse Waddenzee al geruime tijd te kampen hebben met magere broedresultaten (Willems et al. 2005, de Boer et al. 2007, Van Kleunen et al. 2010, Van Kleunen et al. 2012, Koffijberg \& Smit 2013, Koffijberg et al. 2015b, Koffijberg et al. 2016a, Koffijberg et al. 2017). De situatie in de Nederlandse Waddenzee kent bovendien veel overeenkomsten met die van de Duitse en Deense Waddenzee (Thorup \& Koffijberg 2015). Een analyse van alle demografische parameters liet eerder zien dat een laag broedsucces bij de meeste broedvogels een groter probleem is dan veranderingen in jaarlijkse overleving (Van der Jeugd et al. 2014). Dit leidde tot een trilateraal actieplan broedvogels (Koffijberg et al. 2016b) en een op Nederland toegesneden actieplan, opgesteld in opdracht van Programma Rijke Waddenzee (PRW 2018).

Het voorliggende rapport presenteert de resultaten van de broedsucces-monitoring in 2017. De opzet van het rapport is basaal van karakter. Belangrijkste doel is het toegankelijk maken van de monitoringgegevens voor verder gebruik. De presentatie van de resultaten is eveneens basaal van opzet. In de rapportage over 2018 wordt weer een actueel overzicht van de trends in broedsucces opgenomen. 


\section{$2 \quad$ Methode en materiaal}

\subsection{Opzet van het Meetnet Reproductie in de Waddenzee}

Het reproductiemeetnet richt zich primair op het verkrijgen van informatie over het aantal vliegvlugge jongen dat per paar wordt geproduceerd (hierna verder broedsucces genoemd, zie Tekstkader 'Definities nestsucces en broedsucces'. Het broedsucces is een belangrijke parameter die ook voor zogenaamde integratieve populatiemonitoring kan worden gebruikt, omdat het samen met de jaarlijkse overleving het belangrijkste mechanisme achter populatieveranderingen vormt (Reneerkens et al. 2005, Van der Jeugd et al. 2014, Schekkerman et al. 2017).

Het uiteindelijke broedsucces is vooral het resultaat van een optelsom aan factoren die optreden tussen de start van een legsel en het uitvliegen van de jongen. Maar ook voorafgaand aan het broeden speelt onder andere de conditie van de oudervogels een rol, deze kan verlaagd zijn door bijvoorbeeld voedselschaarste voorafgaand aan het broedseizoen (zogenaamde carry-over effecten). Factoren die van belang kunnen zijn tijdens de eifase zijn onder meer predatie of hoge vloeden en tijdens de jongenfase bijvoorbeeld conditie (voedselschaarste) of slecht weer (onderkoeling kuikens).

Om te weten te komen in welk stadium van het broedproces de belangrijkste beperkingen liggen, worden daarom naast het uiteindelijke broedsucces ook zoveel mogelijk gegevens verzameld in de nest- en kuikenfase (zie tabel 2.1 voor een overzicht van verzamelde parameters). Inzicht in het slagen of mislukken van legsels (nestsucces), het uiteindelijke broedsucces en de achterliggende oorzaken bieden aanknopingspunten welke van de factoren in tabel 2.1 van belang zijn. Voor het volgen van nesten wordt aangesloten bij het Meetnet Nestkaarten van Sovon (Van Turnhout 2008). Door de combinatie van het Meetnet Nestkaarten en het Meetnet Reproductie in de Waddenzee kan op efficiënte wijze het broedsucces van kustbroedvogels in de Waddenzee in kaart worden gebracht. Het Tekstkader beschrijft welke definities we hanteren voor nestsucces en broedsucces.

Welke gegevens in het veld uiteindelijk worden verzameld is afhankelijk van de soort. Voor in kolonies broedende soorten (meeuwen en sterns) kan het gehele broedproces met de juiste technieken goed worden gevolgd. Bij meer verspreid of verborgen broedende soorten (bijv. Eider) wordt het volgen in de eifase lastiger, mede ook vanuit oogpunt van verstoring. Kluten daarentegen gaan na het uitkomen van de eieren met hun jongen weg uit de buurt van het nest, en zijn juist in de kuikenfase moeilijker te volgen. De gebruikte werkwijze in het veld moet dus worden afgestemd op het gedrag van de tien meetsoorten (zie verder paragraaf 2.2).

\section{Tekstkader 'Definities nestsucces en broedsucces'}

Dit rapport gaat over het broedsucces van kustbroedvogels in de Waddenzee. De term broedsucces heeft hier exclusief betrekking op het uiteindelijk aantal vliegvlugge jongen per paar (in de gemeten steekproef, of in het hele telgebied, indien in het hele telgebied broedsucces werd gemeten). Het succesvol uitkomen van legsels, elders ook broedsucces genoemd, wordt in dit rapport consequent als nestsucces gedefinieerd. Dit nestsucces kan, al naar gelang de beschikbaarheid van de gegevens, op twee manieren worden bepaald: (1) op de klassieke manier, als het percentage uitgekomen nesten en (2) als nestsucces $H$, bepaald met de Mayfield methode. De Mayfield-methode gaat uit van de dagelijkse overlevingskansen van legsels, in combinatie met de ligduur van een legsel (Beintema 1992). Mayfield-getallen worden alleen opgenomen voor soorten waarvan nesten frequent werden gevolgd en gegevens werden ingevoerd in de Nestkaart-applicatie van Sovon. Voor het overige wordt het klassieke nestsucces gebruikt, dat als handicap heeft dat het nestsucces wordt overschat (Beintema 1992). Alleen in geval van nesten die intensief worden gevolgd, is het klassieke nestsucces vergelijkbaar met nestsucces zoals die uit Mayfield-berekeningen komt. 
De in tabel 2.1 genoemde factoren kunnen binnen de Waddenzee sterk variëren. Zo is bijvoorbeeld het risico van predatie langs de vastelandskust doorgaans groter dan op de eilanden, waar veel landpredatoren (Vos, marterachtigen) ontbreken. Ook is de voedselsituatie niet in de hele Waddenzee gelijk, bijvoorbeeld als gevolg van verschillen tussen de westelijke en de oostelijke Waddenzee in de beschikbaarheid van mosselbanken. Voor een representatief overzicht is het dus van belang om gegevens uit verschillende delen van de Waddenzee te verzamelen. Om een goede spreiding in habitats en ligging van locaties te verkrijgen wordt er in het reproductiemeetnet naar gestreefd om voldoende stratificatie van meetpunten te hebben over gebieden en habitats.

Tabel 2.1. Overzicht van verzamelde parameters in het Meetnet Reproductie in de Waddenzee, onderscheiden naar eifase en kuikenfase. Tevens zijn de belangrijkste factoren genoemd die de uitkomst van deze parameters kunnen beïnvloeden en/of welke indicatorwaarde de resultaten hebben. Het overzicht geeft een algemeen beeld en kan in detail afwijken, afhankelijk van de soort. [Parameters recorded for monitoring breeding success of coastal breeding birds in the Dutch Wadden Sea, including their indicator value.]

\begin{tabular}{|c|c|c|c|}
\hline Parameter & Eifase & Kuikenfase & Factoren van invloed / indicator voor \\
\hline Legselgrootte & $x$ & & -conditie ouders \\
\hline \multirow[t]{4}{*}{ Legbegin } & $x$ & & -conditie ouders \\
\hline & & & -voedselsituatie ter plaatse \\
\hline & & & -habitat (groei vegetatie) \\
\hline & & & -weersomstandigheden (temperatuur) \\
\hline \multirow[t]{4}{*}{ Uitkomstsucces (nest, eieren) } & $x$ & & -predatie \\
\hline & & & -risico overstroming bij stormvloed \\
\hline & & & -risico vertrapping bij begrazing \\
\hline & & & -belasting met contaminanten \\
\hline \multirow[t]{5}{*}{ Vervolg- en tweede legsels } & $x$ & & -conditie ouders \\
\hline & & & -predatie \\
\hline & & & -risico overstroming bij stormvloed \\
\hline & & & -risico vertrapping bij begrazing \\
\hline & & & -belasting met contaminanten \\
\hline \multirow[t]{2}{*}{ Groei (conditie) kuikens } & & $x$ & -voedselsituatie ter plaatse \\
\hline & & & -weersomstandigheden \\
\hline \multirow[t]{4}{*}{ Overleving jongen } & & $x$ & -voedselsituatie ter plaatse \\
\hline & & & -predatie \\
\hline & & & -weersomstandigheden (temperatuur, neerslag en \\
\hline & & & optreden stormvloed) \\
\hline \multirow[t]{3}{*}{ Uitvliegsucces (jongen per paar) } & & $x$ & -voedselsituatie ter plaatse \\
\hline & & & -predatie \\
\hline & & & -weersomstandigheden \\
\hline
\end{tabular}

\subsection{Meetinspanning 2017}

De coördinatie en de uitvoering van het veldwerk voor het reproductiemeetnet wordt uitgevoerd door Sovon Vogelonderzoek Nederland (grootste deel Waddengebied) en Wageningen Marine Research (intensieve populatiestudie Scholekster Texel). Voor de aansturing van het veldwerk werd geput uit de poule aan vrijwilligers, vogelwachters en andere medewerkers van terreinbeheerders, aangevuld met professionele inzet van veldmedewerkers van Sovon. Door de jaren heen gaat het om een betrekkelijk kleine groep deelnemers met veel expertise. In een aantal gevallen werden gegevens van andere projecten en initiatieven gebruikt, zoals de monitoring van sterns in de Eemshaven in het kader van overlast bij daar gevestigde bedrijven, onderzoek aan Kleine Mantelmeeuwen voor het Gemini-project op Schiermonnikoog en monitoring op de Dollardkwelder voor de dijkverbetering (Bos et al. 2017). Voor gegevens van Lepelaar wordt samengewerkt met de Werkgroep Lepelaar, die haar gegevens verzameld voor het Metawad project. De vogelwachters van Griend en Rottumerplaat meten voor verschillende soorten het broedsucces (Lutterop \& Kasemir 2018). Gegevens van het onderzoek aan grote meeuwen in de Kelderhuispolder op Texel van het NIOZ werden helaas niet beschikbaar gesteld voor het in dit rapport gepresenteerde overzicht. 
Alle veldmedewerkers, voor zover aangestuurd door Sovon, werden voorzien van een speciale instructie, afgeleid van de Engelstalige trilaterale handleiding voor het monitoren van broedsucces (Koffijberg et al. 2011). Op Texel werd voor Grote Stern gebruik gemaakt van een drone (Spaans et al. 2018). De uitvoering van het veldwerk verschilt per soort. Oosterhuis et al. (2004) en Koffijberg et al. (2011) geven een overzicht van de gangbare methodieken per soort en beschrijven de methodes in detail. Tabel 2.2 geeft op hoofdlijnen inzicht hoe de gegevens per soort werden verzameld. Richtlijnen voor het uitvoeren van nestonderzoek staan ook per soort online op www.sovon.nl ('Vogelinfo'), gebruik van nestkaarten voor het Meetnet Nestkaarten op www.sovon.nl/nl/onderzoek/nestonderzoek.

Tabel 2.2. Overzicht van de in deze studie gehanteerde methodes per soort (voor details zie Oosterhuis et al. 2004, Koffijberg et al. 2011). [Overview of methods used during fieldwork in the monitoring scheme of breeding success of coastal breeding birds in the Dutch Wadden Sea.]

\begin{tabular}{|c|c|}
\hline Soort & Werkwijze \\
\hline Eider & Telling grote jongen rond 1 juli; volgen beperkt aantal nesten op Vlieland \\
\hline Scholekster & Volgen nesten en telling (bijna) vliegvlugge jongen op locaties met bekend aantal broedparen \\
\hline Kluut & Volgen nesten en telling (bijna) vliegvlugge jongen op locaties met bekend aantal broedparen \\
\hline $\begin{array}{l}\text { Kleine } \\
\text { Mantelmeeuw }\end{array}$ & $\begin{array}{l}\text { Volgen nesten en schatten jongenproductie afzonderlijke kolonie, waar nodig door gebruik te } \\
\text { maken van enclosure }\end{array}$ \\
\hline Zilvermeeuw & $\begin{array}{l}\text { Volgen nesten en schatten jongenproductie afzonderlijke kolonie, waar nodig door gebruik te } \\
\text { maken van enclosure }\end{array}$ \\
\hline Visdief & $\begin{array}{l}\text { Volgen nesten en schatten jongenproductie afzonderlijke kolonie, waar nodig door gebruik te } \\
\text { maken van enclosure }\end{array}$ \\
\hline Noordse Stern & $\begin{array}{l}\text { Volgen nesten en schatten jongenproductie afzonderlijke kolonie, bij voorkeur door gebruik te } \\
\text { maken van enclosure }\end{array}$ \\
\hline
\end{tabular}

In het broedseizoen van 2017 werden in totaal voor 76 soort x gebiedscombinaties gegevens verzameld (tabel 2.3, figuur 2.1), iets meer dan de 65 in 2016. Scholekster, Kokmeeuw en Visdief werden het meest intensief en het meest verspreid over de Waddenzee onderzocht, zij het soms wel met kleine steekproeven. In de meeste gevallen worden voor specifieke soorten jaarlijks dezelfde locaties gevolgd. Terschelling en de Friese Waddenkust zijn niet vertegenwoordigd in het meetnet, ondanks gerichte pogingen om hier via de terreinbeheerder of vrijwilligers broedsucces-gegevens te verzamelen. Met name langs de Friese Waddenkust bevinden zich belangrijke kolonies van Kluut en Noordse Stern, waarvan gegevens zouden bijdragen aan de representativiteit van het meetnet.

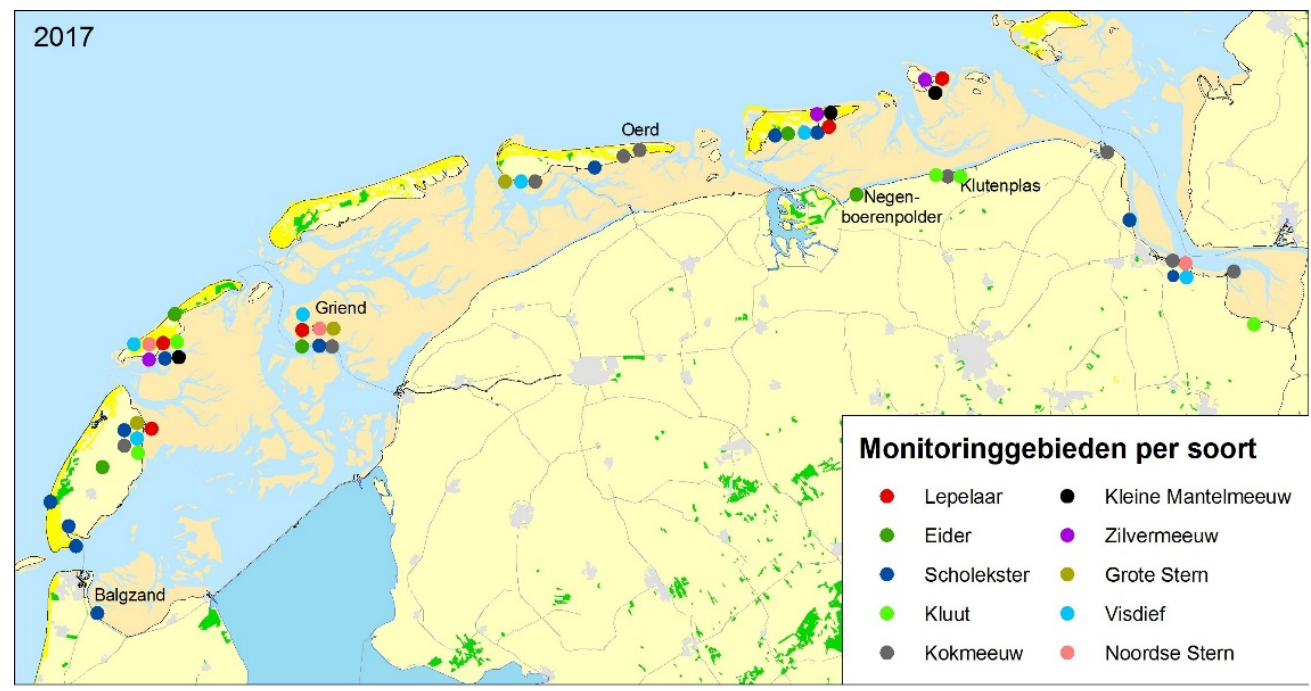

Figuur 2.1. Overzicht van het in 2017 verzamelde materiaal van reproductiegegevens voor alle meetnetsoorten. Weergegeven is op welke locaties voor welke soorten gegevens werden verzameld. [Overview of data collection in 2017 (combinations of species $x$ site, multiple samples at one site only presented once).] 
Tabel 2.3. Overzicht van het in 2017 verzamelde materiaal van reproductiegegevens voor alle bestudeerde soorten. Weergegeven is het aantal gebieden/kolonies waar gegevens werden verzameld, gegroepeerd per regio. [Overview data collection in 2017. For each region, the number of sample sites is given (usually a colony or specific breeding site).]

\begin{tabular}{|c|c|c|c|c|c|c|c|c|c|c|}
\hline Gebied / regio & $\frac{\frac{1}{d}}{\frac{10}{0}}$ & $\frac{10}{\frac{1}{0}}$ & $\frac{\frac{1}{4}}{\frac{2}{4}}$ & $\frac{3}{3}$ & $\begin{array}{l}3 \\
\frac{3}{3} \\
\frac{1}{0}\end{array}$ & $\frac{\text { d) }}{2}$ & $\begin{array}{l}3 \\
\frac{3}{0} \\
\frac{3}{0} \\
\frac{0}{5} \\
\frac{1}{N}\end{array}$ & 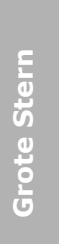 & $\frac{4}{\frac{4}{5}}$ & 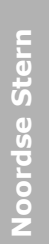 \\
\hline Balgzand & - & - & 1 & - & - & - & - & - & - & - \\
\hline Friese kust & - & - & - & - & - & - & - & - & - & - \\
\hline Noordkust Groningen & - & 1 & - & 2 & 1 & - & - & - & - & - \\
\hline Eemshaven & - & - & - & - & 2 & - & - & - & 1 & 1 \\
\hline Eems & - & - & 1 & - & - & - & - & - & - & - \\
\hline Havengebied Delfzijl & - & - & 1 & - & 2 & - & - & - & 2 & 1 \\
\hline Punt van Reide & - & - & - & - & 1 & - & - & - & - & - \\
\hline Dollard & - & - & - & 1 & - & - & - & - & - & - \\
\hline Texel & 1 & 1 & 4 & 6 & 4 & - & - & 2 & 4 & - \\
\hline Vlieland & 2 & 1 & 1 & 1 & - & 1 & 1 & - & 2 & 2 \\
\hline Griend & 1 & 1 & 1 & - & 1 & - & - & 1 & 1 & 1 \\
\hline Terschelling & - & - & - & - & - & - & - & - & - & - \\
\hline Ameland & - & - & 1 & - & 3 & - & - & 1 & 1 & 1 \\
\hline Schiermonnikoog & 1 & 1 & 3 & - & - & 1 & 1 & - & 1 & - \\
\hline Rottum & 1 & - & - & - & - & 1 & 1 & - & - & - \\
\hline Alle gebieden & 6 & 5 & 13 & 10 & 14 & 3 & 3 & 4 & 12 & 6 \\
\hline
\end{tabular}

\subsection{Verwerking van de gegevens}

Gegevens over de lotgevallen van nesten werden verwerkt via het Meetnet Nestkaarten van Sovon/CBS. Dit project is onderdeel van het Netwerk Ecologische Monitoring en heeft onder andere tot doel verschuivingen in het begin van de eileg te volgen, als graadmeter voor klimaatveranderingen (zie Van Turnhout 2008). Invoer van de veldgegevens gebeurt met de speciale software 'Nestkaart' (zie bijlage 4 in Willems et al. 2005), en verloopt geheel digitaal. De ingevoerde gegevens zijn vervolgens gekoppeld aan de database van het Meetnet Reproductie. Deze database is online toegankelijk voor de waarnemers. In deze database is informatie over de locatie, soort, (globale) lotgevallen van legsels, lotgevallen van kuikens, het aantal uitgevlogen jongen per paar en eventuele aanvullende opmerkingen opgeslagen. Voor de analyse worden beide databases uitgelezen en gecontroleerd op onwaarschijnlijkheden en dubbele records. Uit de definitieve output werden de tabellen voor deze rapportage gegenereerd. In geval van twijfel over de kwaliteit van de gegevens, of in geval van sommige hele kleine steekproeven, werden de gegevens niet meegenomen in de bespreking van de resultaten.

\subsection{Analyses en presentatie gegevens}

Uit de verzamelde gegevens zijn primair twee belangrijke parameters geanalyseerd, te weten het nestsucces (uitkomstsucces) en het broedsucces (het aantal vliegvlugge jongen per broedpaar). Het nestsucces wordt in dit rapport zoveel mogelijk gebaseerd op analyses met de Mayfield-methode 
(Beintema 1992); alleen bij kleine steekproeven wordt teruggegrepen op het klassieke nestsucces, ofwel de verhouding succesvolle/niet-succesvolle nesten. De laatste leidt in de meeste situaties (tenzij er vrijwel dagelijks een controle plaatsvindt) tot een overschatting van het broedsucces (Beintema 1992). Mayfield gaat uit van een dagelijkse overlevingskans $p$ : de kans dat een nest dat vandaag wordt gevonden er ook morgen nog ligt. Door deze kansen te bepalen over de hele eifase ('ligduur') wordt het uitkomstsucces $H$ berekend (zie Willems et al. 2005 voor verdere details).

Het uiteindelijke aantal vliegvlugge jongen per paar werd berekend door het aantal (bijna) vliegvlugge jongen te delen door het vastgestelde aantal broedparen, hetzij in de steekproef waar broedsucces werd gemonitord, hetzij in het hele telgebied, of in de hele kolonie. Bij Eidereend wordt het aantal jongen zelfs bepaald voor een heel eiland. Dit gebeurt via soort-specifieke methodes (zie eerder). Voor Eider en Kluut worden voor dat doel speciale jongentellingen georganiseerd, voor de in kolonies broedende meeuwen en sterns wordt dit deels door middel van enclosures, en deels door middel van vangst-terugvangst methodieken bepaald (zie Koffijberg et al. 2011 voor details). Voor Scholekster werden in een klein aantal BMP-plots (t.b.v. de reguliere broedvogelinventarisaties) begin juli een jongentelling uitgevoerd. In sommige gevallen was alleen een schatting mogelijk van het aantal uitgevlogen jongen.

\subsection{Bijzondere omstandigheden in 2017}

Hoewel het voorjaar van 2017 in het algemeen werd gekenmerkt door zacht, droog en zonnig weer (na een koude start), vond er gedurende het broedseizoen eenmaal een heuse zomerstorm plaats. Op 6 juni koerste een lagedrukgebied net ten westen van Nederland naar het noorden, en zorgde aan de kust voor een stormachtige wind (8-9 Bft.) en een hoog tij. Dit viel bovendien samen met lage temperaturen en veel regen (www.knmi.nl). Op 25 juni werd nogmaals een hoog tij gemeten, maar de gevolgen hiervan waren minder groot dan op 6-7 juni. Details voor effecten op de soorten worden in de soortbesprekingen in hoofdstuk 3 gegeven. 



\section{Resultaten}

\subsection{Algemeen}

In dit hoofdstuk worden de resultaten van de tien meetnetsoorten afzonderlijk besproken. Per soort wordt een beknopte beschrijving gegeven van het voorkomen en de trends in de Waddenzee tot en met 2017, afgeleid van de broedvogeltellingen die in het kader van het Netwerk Ecologische Monitoring (Meetnet Broedvogels van Sovon/CBS) worden uitgevoerd (zie ook Boele et al. 2018). Trends in aantallen broedparen worden weergegeven als indexwaarde, afgezet tegen het eerste jaar van de reeks tellingen (1990) (zie verder Boele et al. 2018 voor wijze van berekening). Voor de relevante soorten wordt de huidige broedpopulatie afgezet tegen de instandhoudingsdoelstellingen zoals die in het Natura 2000-beheerplan voor de Waddenzee worden genoemd (zie ook www.sovon.nl onder vogelinfo en gebieden).

Vervolgens presenteren we basale informatie over het broedsucces in 2017. Eventueel worden beperkingen van de gegevens aangegeven (kleine steekproef). Om de soortteksten op te stellen, is veel informatie ontleend aan eerder verschenen rapportages over het reproductiemeetnet Waddenzee (Willems et al. 2005, De Boer et al. 2007, Van Kleunen et al. 2010, 2012, Koffijberg et al. 2015b, Koffijberg et al. 2016a, Koffijberg et al. 2017). Tevens is gebruik gemaakt van het internationale overzicht dat voor TMAP is gemaakt door Thorup \& Koffijberg (2015). Het aantal jongen dat nodig is om de populatie op z'n minst stabiel te houden is ontleend aan Koffijberg \& Smit (2013), zie ook Thorup \& Koffijberg (2015) voor aanvullingen. Specifieke bronnen in de tekst worden alleen genoemd als het niet om één van de bovenstaande publicaties gaat.

\subsection{Lepelaar Platalea leucorodia - Eurasian Spoonbill}

Ruim de helft van alle Nederlandse Lepelaars broedt in de Waddenzee. Na een langere periode van sterke groei begint de toename nu af te vlakken als gevolg van dichtheids-afhankelijke effecten op broedsucces en overleving (Lok et al. 2009, Lok et al. 2013, Oudman et al. 2017). In de westelijke Waddenzee was in 2017 voor het eerst sprake van een duidelijke afname ten opzichte van een jaar eerder (figuur 3.1). De omvang van de broedpopulatie ligt nog altijd duidelijk boven de geformuleerde instandhoudingsdoelstelling voor de Waddenzee.

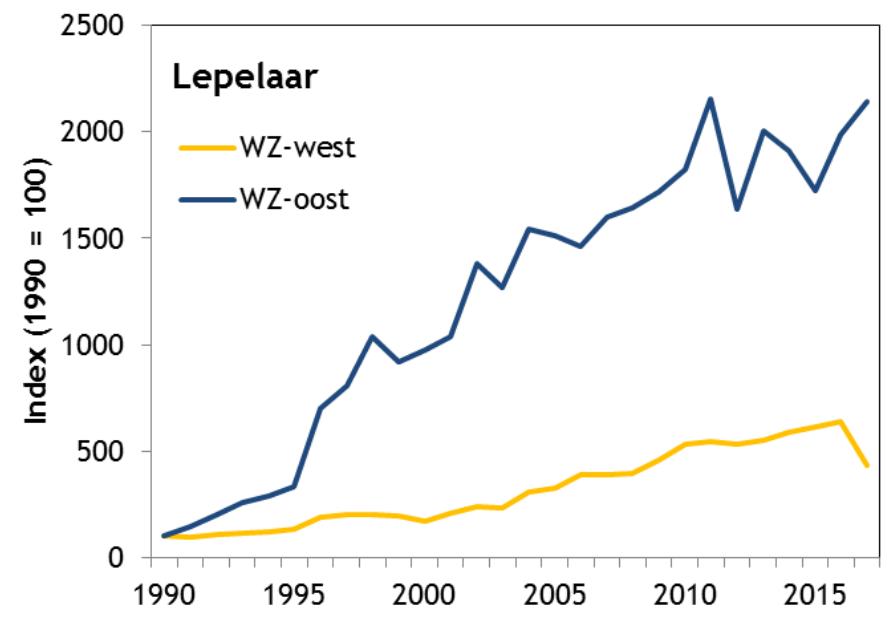

Figuur 3.1. Trend van Lepelaars als broedvogel in de Waddenzee (index), gesplitst naar Westelijke Waddenzee (west van wantij Terschelling) en oostelijke Waddenzee (tot Eemshaven). Gegevens broedvogelmeetnet Sovon/CBS. [Trends in breeding Eurasian Spoonbill (expressed as index) in the western and eastern Wadden Sea.] 
Het broedsucces, gemeten door de Werkgroep Lepelaar in het kader van het Metawad project in zes kolonies op vijf eilanden, liep uiteen van 0,2 jong per paar op Rottumerplaat tot 1,03 jong per paar op Griend. In de meeste kolonies bedroeg het broedsucces 0,6-0,8 jong per paar. Deze waarden passen goed bij de resultaten van voorgaande jaren, maar liggen gemiddeld duidelijk lager dan die van de periode voor 2010. Op de lange termijn (zowel sinds 1992 als sinds de start van het meetnet in 2005) is in de Nederlandse Waddenzee sprake van een significante afname van het broedsucces (figuur 4.2 in Koffijberg et al. 2017).

\subsection{Eider Somateria mollissima - Common Eider}

De Waddenzee herbergt vrijwel de hele Nederlandse populatie aan broedende Eiders. Broedpopulaties in de Duitse en Deense Waddenzee zijn erg klein in vergelijking met die in Nederland. Vanaf de start van het broedvogelmeetnet in 1990 is het aantal broedende Eiders significant afgenomen, in vergelijkbare mate in de westelijke Waddenzee als in de oostelijke Waddenzee (figuur 3.2). Het verloop van het aantal broedparen in de Waddenzee kende in de afgelopen dertig jaar sterke schommelingen en periodiek massale sterfte, veroorzaakt door voedselschaarste (o.a. Camphuysen et al. 2002, Kats 2007). Daarnaast kan een deel van de fluctuaties worden veroorzaakt door telproblemen op de Waddeneilanden. Nog steeds zit het aantal broedvogels in de Waddenzee onder de geformuleerde instandhoudingsdoelstelling in het Natura 2000-beheerplan.

In de studiekolonie op Vlieland bedroeg het nestsucces (Mayfield) bij 28 gevolgde nesten 34,7\%. Dit ligt in dezelfde orde van grootte als de lange termijn reeks voor dit gebied, maar er waren duidelijk meer succesvolle nesten dan in 2015 en 2016 (nestsucces resp. 20,6 en 21,9; zie tabel 4.1 in Koffijberg et al. 2017).

Jongentellingen werden op vijf eilanden uitgevoerd en leverden 0,01 jong per paar (Vlieland) tot 1,03 jong per paar (Schiermonnikoog) op. Het lage succes op Vlieland kende parallellen op Griend $(0,31$ jong per paar) en contrasteert met het iets hogere nestsucces dat op Vlieland werd gemeld. Op Texel $(0,74$ jong per paar) en op de kwelder van de Julianapolder aan de Groninger kust (0,97 jong per paar) was het aantal jongen per vrouwtje beduidend groter. Het ongewogen gemiddelde van alle tellingen (0,56 jong per paar) past goed bij de broedsuccessen die in de afgelopen jaren werden gerapporteerd, maar zijn aan de lage kant voor een stabiele populatie. Omdat belangrijke eilanden (o.a. Terschelling) ontbreken in de steekproef en de spreiding groot is (vergelijk Vlieland en Schiermonnikoog) zijn de cijfers ook met enig voorbehoud te interpreteren. Over de periode 20052016 kon geen significante trend in het broedsucces worden vastgesteld (zie figuur 4.4 in Koffijberg et al. 2017).

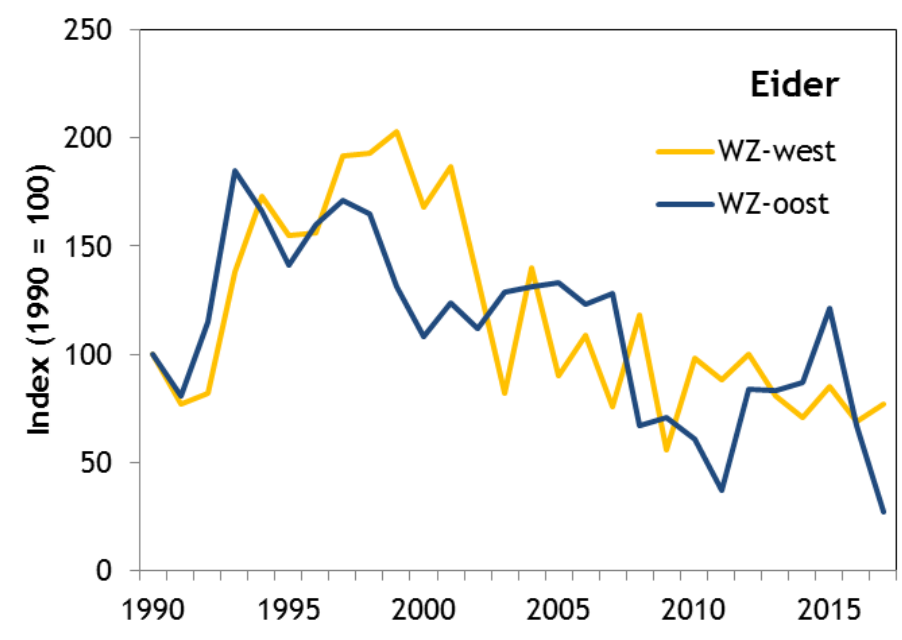

Figuur 3.2. Trends van Eider als broedvogel in de Waddenzee (index), gesplitst naar Westelijke Waddenzee (west van wantij Terschelling) en oostelijke Waddenzee (tot Eemshaven). Gegevens broedvogelmeetnet Sovon/CBS. [Trends in breeding Eider in the western and eastern Wadden Sea.] 


\subsection{Scholekster Haematopus ostralegus - Eurasian Oystercatcher}

De Scholekster is één van de wijdst verspreide broedvogels in de Nederlandse Waddenzee, met hoge dichtheden op de kwelders en in de polders van de Waddeneilanden. De soort neemt al jaren af in aantal; sinds 1990 in de Waddenzee met gemiddeld 4\% per jaar. In 2017 resteerde minder dan de helft van het aantal dat in 1990 werd geteld, maar een verdere afname lijkt in de afgelopen zes jaar niet meer plaats te vinden. De trend in de Waddenzee verloopt parallel aan de algehele negatieve ontwikkeling van de hele Nederlandse broedpopulatie, inclusief de Scholeksters die broeden in het boerenland in het binnenland. Opvallend genoeg doet de kleine populatie Scholeksters in de EemsDollard het beter (stabiele trend) dan in de oostelijke en westelijke Waddenzee (figuur 3.3).

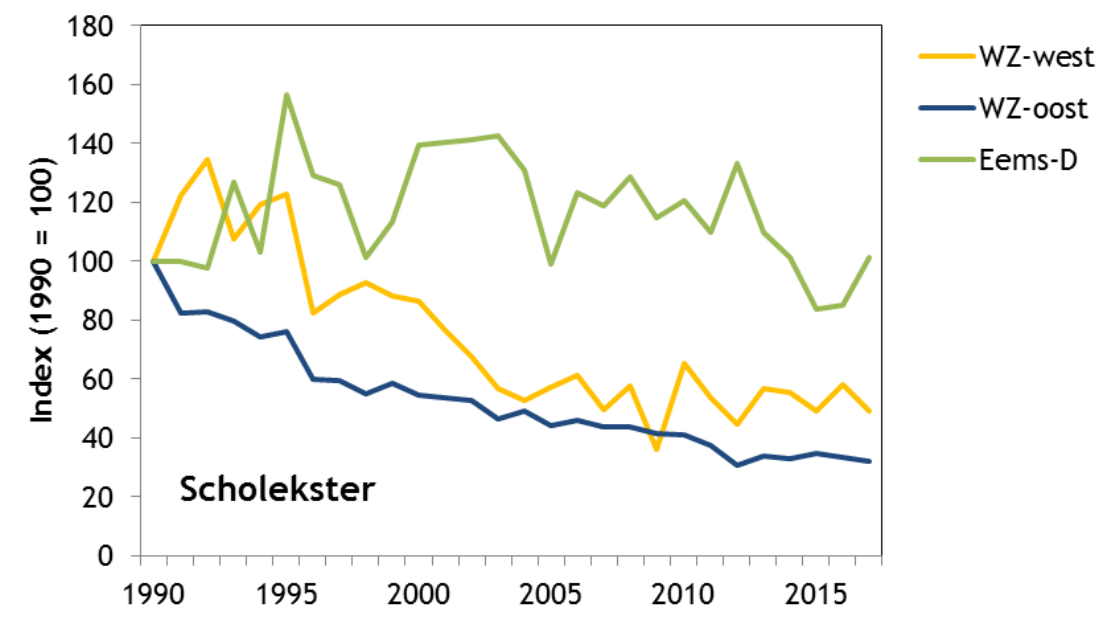

Figuur 3.3. Trends van Scholekster als broedvogel in de Waddenzee (index), gesplitst naar Westelijke Waddenzee (west van wantij Terschelling), oostelijke Waddenzee (tot Eemshaven) en Eems-Dollard (Eemshaven-Dollard). Gegevens broedvogelmeetnet Sovon/CBS. [Trends in breeding Eurasian Oystercatcher (expressed as index) in the western, eastern Wadden Sea and Eems-Dollard estuary.]

De Scholekster behoort wat betreft broedsucces tot de best onderzochte soorten in de Waddenzee, mede door lang lopende populatiestudies op Texel en Schiermonnikoog. Gegevens omtrent het nestsucces hebben vooralsnog betrekking op klassieke uitkomstpercentages, die uiteenliepen van 0 (meer locaties) tot 69\% (terrein Joost Dourleinkazerne op Texel). Het gemiddelde van alle locaties bedroeg $25 \%$, dus hooguit een vierde van het aantal nesten was succesvol (klassieke nestpercentages tenderen naar een overschatting van nestsucces). Compleet mislukte nesten kwamen voor langs de Eems ten noorden van Delfzijl en op Texel (De Petten / Kikkert) en waren vooral getroffen door een hoog predatierisico. Naast het kazerneterrein op Texel kwamen alleen in de haven van Delfzijl meer dan de helft ( $56 \%$ ) van de nesten uit. De oorzaken voor mislukken verschilden per locatie en hadden te maken met predatie, vertrapping door vee (Oosterkwelder Schiermonnikoog) en door stormvloeden.

Ook de jongenproductie bleef in 2017 ver achter bij wat noodzakelijk wordt geacht om de populatie stabiel te houden. Het aantal vliegvlugge jongen per paar liep uiteen van 0 (meer locaties) tot 1,48 jong per paar (haven Delfzijl) (ongewogen gemiddelde 0,24 jong per paar). Gebieden met heel weinig jongen ( $<0,10$ jong per paar) waren het hoge deel van de Oosterkwelder op Schiermonnikoog, Griend, de Vliehors op Vlieland, Ottersaat op Texel en De Petten/Kikkert op Texel. De geringe jongenproductie in 2017 past goed in het beeld uit voorgaande jaren, en het valt op dat niet alleen gebieden langs de vastelandskust worden getroffen, maar ook de eilanden. 


\subsection{Kluut Recurvirostra avosetta - Pied Avocet}

Kluten komen in de Waddenzee vooral langs de Fries-Groningse kust voor, maar nemen daar al jaren sterk af. In de hele Waddenzee resteerde in 2017 nog maar een kwart van het aantal dat in 1990 werd geteld; het was het laagste aantal in de reeks gegevens vanaf 1990. In de oostelijke Waddenzee (waarin de belangrijke Friese en Groningse kwelders liggen) was de afname veel sterker (gemiddeld $8 \%$ per jaar) dan in de westelijke Waddenzee (5\%) (figuur 3.4). In de Eems-Dollard regio (voornamelijk Dollard) vertoont de trend sterke fluctuaties, maar is over de hele periode eveneens sprake van een sterke afname. Het huidige aantal broedparen in de Waddenzee ligt ver onder de instandhoudings-doelstellingen voor Natura 2000.

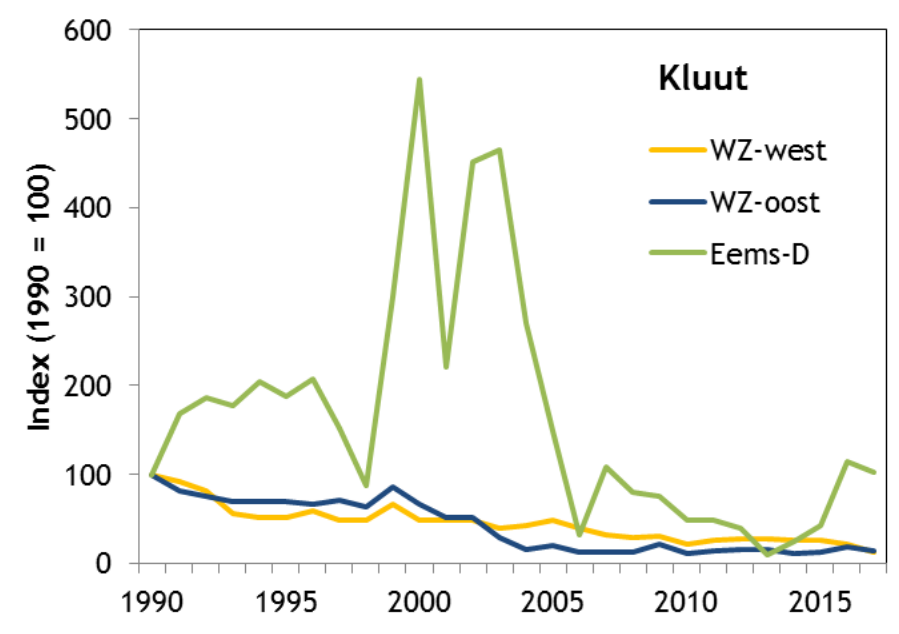

Figuur 3.4. Trend van Kluut als broedvogel in de Waddenzee (index), gesplitst naar Westelijke Waddenzee (west van wantij Terschelling), oostelijke Waddenzee (tot Eemshaven) en Eems-Dollard (EemshavenDollard). Gegevens broedvogelmeetnet Sovon/CBS. [Trends in breeding Pied Avocet (expressed as index) in the western, eastern Wadden Sea and Eems-Dollard estuary.]

In twee gebieden (Klutenplas Groninger kust en Dollardkwelder) werden nesten van Kluten gevolgd. In de Klutenplas mislukten alle nesten in een vroeg stadium, zodat onvoldoende gegevens beschikbaar kwamen om het nestsucces goed te bepalen. Ondanks het predatiewerend elektrisch raster dat door de beheerder was opgesteld wisten predatoren toch het gebied binnen te komen, en mislukten veel broedsels (De Boer 2018). In de Dollard werd op twee locaties een steekproef aan nesten gevolgd, met een nestsucces van resp. 31,2 en 25,0\% (zie ook Bos et al. 2017). Op geen enkele plaats kwam dus meer dan een derde van de nesten uit. Jongentellingen leverden op de Dollardkwelder nul jongen op en langs de Groninger kust 0,22 jongen per paar. Voor het eerst werden in 2017 op grotere schaal jongentellingen op de eilanden uitgevoerd, en wel in de binnendijkse wetlands op Texel. Het aantal jongen in drie gebieden bedroeg resp. 0, 0,36 en 0,57 jong per paar en is dus gemiddeld groter dan op de locaties op het vasteland. Het gaat evenwel om kleine kolonies, die voor de gehele Waddenzee de slechte broedresultaten op het vasteland niet kunnen compenseren (aantallen broedvogels op de eilanden bovendien klein). Hoewel het broedsucces op langere termijn grote variaties vertoont (20052016 geen significante trend, zie figuur 4.8 in Koffijberg et al. 2017) is het te laag voor een stabiele populatie.

\subsection{Kokmeeuw Chroicocephalus ridibundus - Black- headed Gull}

Het aantal broedende Kokmeeuwen in de Waddenzee neemt sinds 1990 significant af, en die afname is in de oostelijke Waddenzee (populatie crash in 2002) nog veel sterker dan in de westelijke Waddenzee (voornamelijk bepaald door de situatie op Griend) (figuur 3.5). De kleinere aantallen in de Eems-Dollard regio vertonen sterke schommelingen. 
In 2017 waren alleen gegevens beschikbaar over het broedsucces. In acht van de veertien onderzochte kolonies kwamen in het geheel geen jongen groot, waaronder ook de grote kolonie op Griend. In een door een elektrisch raster beschermde kolonie in het havengebied van Delfzijl en op de Punt van Reide kwamen resp. 1,05 en 0,70 jongen per paar groot, in een onbeschermde kolonie in de Eemshaven 0,74. In de overige kolonies ging het om hooguit 0,13 jong per paar. De in 2017 verzamelde gegevens bevestigen de slechte broedresultaten die ook in voorgaande jaren werden vastgesteld, en zullen de over 1995-2016 gemeten significante negatieve trend in broedsucces (figuur 4.10 in Koffijberg et al. 2017) niet onderbreken. In ieder geval in de Eems-Dollard regio hebben kolonies die tegen predatie worden beschermd betere broedresultaten dan kolonies zonder die bescherming. Dit wijst er op dat in ieder geval langs de vastelandskust predatierisico een belangrijke oorzaak is van mislukken (en lage aantallen broedparen).

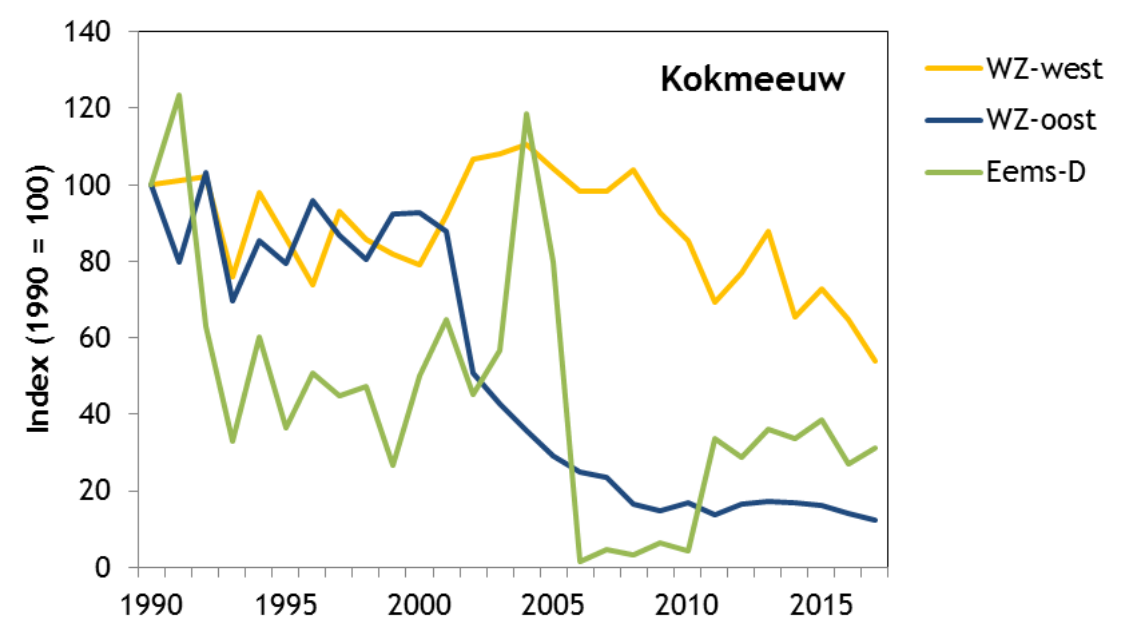

Figuur 3.5. Trend van Kokmeeuw als broedvogel in de Waddenzee (index), gesplitst naar Westelijke Waddenzee (west van wantij Terschelling), oostelijke Waddenzee (tot Eemshaven) en Eems-Dollard (Eemshaven-Dollard). Gegevens broedvogelmeetnet Sovon/CBS. [Trends in breeding Black-headed Gull (expressed as index) in the western, eastern Wadden Sea and Eems-Dollard estuary.]

\subsection{Kleine Mantelmeeuw Larus fuscus - Lesser Black- backed Gull}

De verspreiding van Kleine Mantelmeeuwen kent een zwaartepunt in de duinen en op de strandvlaktes op de Waddeneilanden. Over de hele Nederlandse Waddenzee gerekend nam de populatie op lange termijn toe, maar is recenter sprake van een stabilisatie, met vooral in de westelijke Waddenzee plaatselijk ook afnames (figuur 3.6). Door onvolledige telreeksen in een aantal grote kolonies op Terschelling en Texel zijn de recente trends met enige onzekerheden omgeven. Voor het Natura 2000gebied Waddenzee liggen de aantallen rond de geformuleerde instandhoudingsdoelstelling voor Natura 2000. In de duinen van Texel en Vlieland liggen ze er boven.

In drie kolonies verspreid over de Waddenzee werden gegevens verzameld (Vliehors/Vlieland, Oosterkwelder Schiermonnikoog en Rottumerplaat). Het nestsucces (Mayfield) was in de steekproef op Rottumerplaat (100\%) en Schiermonnikoog (84,0\%) hoger dan op de Vliehors $(59,8 \%)$, maar ze sluiten goed aan bij nestgegevens uit 2006-2016. Het aantal vliegvlugge jongen was op Schiermonnikoog evenwel laag (0,30 jong per paar) vergeleken met Rottumerplaat $(0,54)$. Op Vlieland kwamen 0,20 jong per paar groot. Op Rottumerplaat en Vlieland beïnvloedden predatie en voedselgebrek de broedresultaten. De broedresultaten passen bij de reeks die in 2005-2016 werd verzameld, maar zijn aan de lage kant om de populatie stabiel te houden. De in 2005-2016 vastgestelde positieve tendens in broedsucces (figuur 4.12 in Koffijberg et al. 2017) werd in 2017 niet bevestigd. 


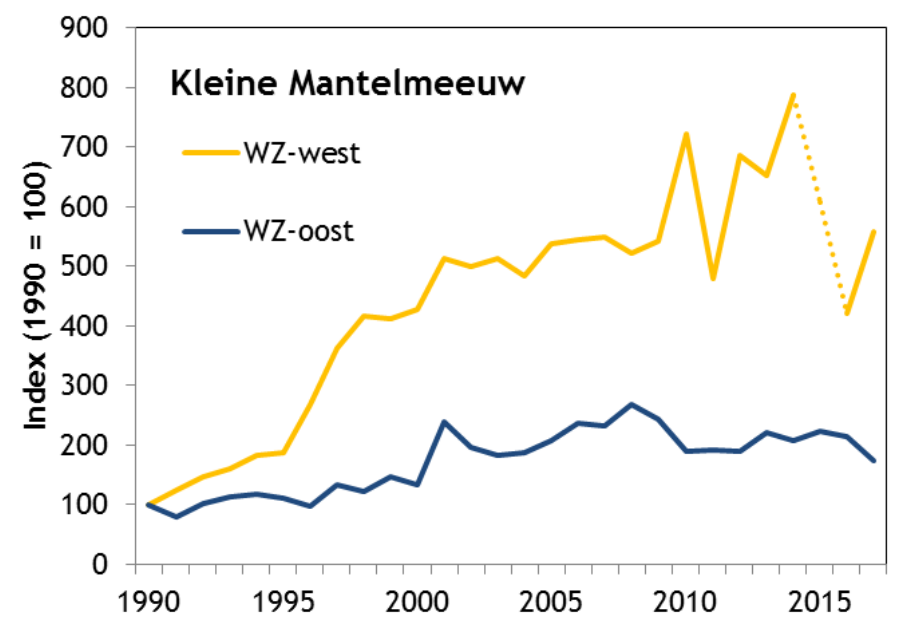

Figuur 3.6. Trend van Kleine Mantelmeeuw als broedvogel in de Waddenzee (index), gesplitst naar Westelijke Waddenzee (west van wantij Terschelling) en oostelijke Waddenzee (tot Eemshaven). Gegevens broedvogelmeetnet Sovon/CBS. Periode 2014-2016 onzeker in verband met lage teldekking en groot aandeel bijgeschatte kolonies. [Trends in breeding Lesser Black-backed Gull (expressed as index) in the western and eastern Wadden Sea. Note low coverage (and high amount of estimated data) in 2014-2016 which may result in less reliable trend.]

\subsection{Zilvermeeuw Larus argentatus - Herring Gull}

Het aantal broedende Zilvermeeuwen in de Waddenzee nam sinds 1990 jaarlijks met gemiddeld $3 \%$ af en bedroeg in 2017 minder dan de helft van het aantal in 1990. Afgezien van enkele fluctuaties, lopen de ontwikkelingen in de westelijke Waddenzee en de oostelijke Waddenzee goed met elkaar in de pas. Net als Kleine Mantelmeeuw broeden Zilvermeeuwen voornamelijk op de eilanden. De kleine populatie in de Eems-Dollardregio (voornamelijk industrieterrein Delfzijl, niet afgebeeld in figuur 3.7) nam over de langere termijn eveneens af, maar kent meer fluctuaties en lag in 2017 rond hetzelfde niveau als in 1990.

Onderzoek aan broedsucces vond in dezelfde gebieden plaats als Kleine Mantelmeeuw (beide soorten broeden ook gemengd). Gegevens omtrent het nestsucces (Mayfield) waren ook heel vergelijkbaar met die van Kleine Mantelmeeuw, met resp. 100,0\% en 85,0\% op Rottumerplaat en Schiermonnikoog en $39,8 \%$ op Vlieland. Het uiteindelijke broedsucces was hoger dan bij Kleine Mantelmeeuw en liep uiteen van 0,45 (Vlieland) tot 0,89 (Rottumerplaat) jong per paar. Op Schiermonnikoog werden 0,55 jong per paar vliegvlug. Deze waardes liggen in dezelfde orde van grootte als de resultaten in voorgaande jaren en zijn gemiddeld duidelijk hoger dan bij Kleine Mantelmeeuw.

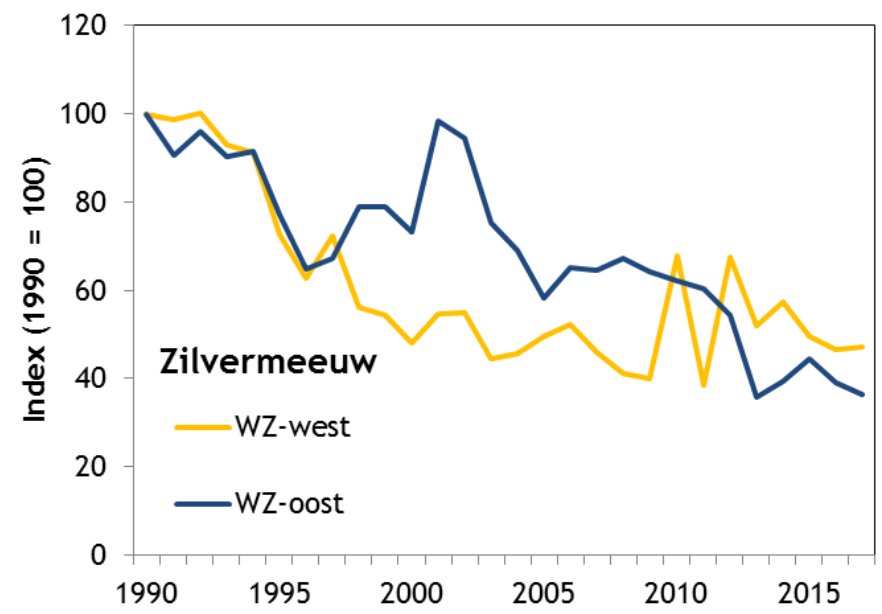

Figuur 3.7. Trend van Zilvermeeuw als broedvogel in de Waddenzee (index), gesplitst naar Westelijke Waddenzee (west van wantij Terschelling) en oostelijke Waddenzee (tot Eemshaven). Gegevens broedvogelmeetnet Sovon/CBS. [Trends in breeding Herring Gull (expressed as index) in the western and eastern Wadden Sea.] 


\subsection{Grote Stern Sterna sandvicensis - Sandwich Tern}

In 2017 hebben 11.752 paar Grote Sterns in de Waddenzee gebroed, verspreid over vijf kolonies (incl. twee paar op de Richel). De kwelder van Hollum op Ameland en de twee binnendijkse kolonies op Texel (Utopia en Wagejot) leverden daarvan het grootste aandeel. Op Griend (1503 paar) herstelde de kolonie zich enigszins van de inzinking in 2016, maar bleef het aantal nesten ver achter bij de situatie van voor 2013 (Lutterop \& Kasemier 2018). Voor de hele Waddenzee vertoont het aantal broedparen sinds 1990 een positieve trend (figuur 3.8), maar duidelijk is ook dat er grote fluctuaties en grote verschuivingen in de verspreiding gaande zijn (toename Ameland en Texel, afname Griend).

In alle vier de grote kolonies werd het broedsucces bepaald (geen nestgegevens). Vergeleken met voorgaande jaren was het aantal vliegvlugge jongen per paar groter. De kolonie van Wagejot op Texel $(0,81)$ en Griend $(0,70$ jong per paar) presteerden het beste. Op Griend was het broedsucces sinds 2010 niet meer zo hoog geweest (Lutterop \& Kasemier 2018). Het broedsucces in Utopia bleef iets achter bij deze cijfers (0,55 jong per paar). De kolonie op de kwelder van Hollum op Ameland mislukte geheel vanwege predatie door onvolwassen Zilvermeeuwen. Na de periode van slecht weer en hoog water begin juni, verlieten de Kokmeeuwen het gebied, en faciliteerden daarmee de predatie door grote meeuwen (Engelmoer 2018).

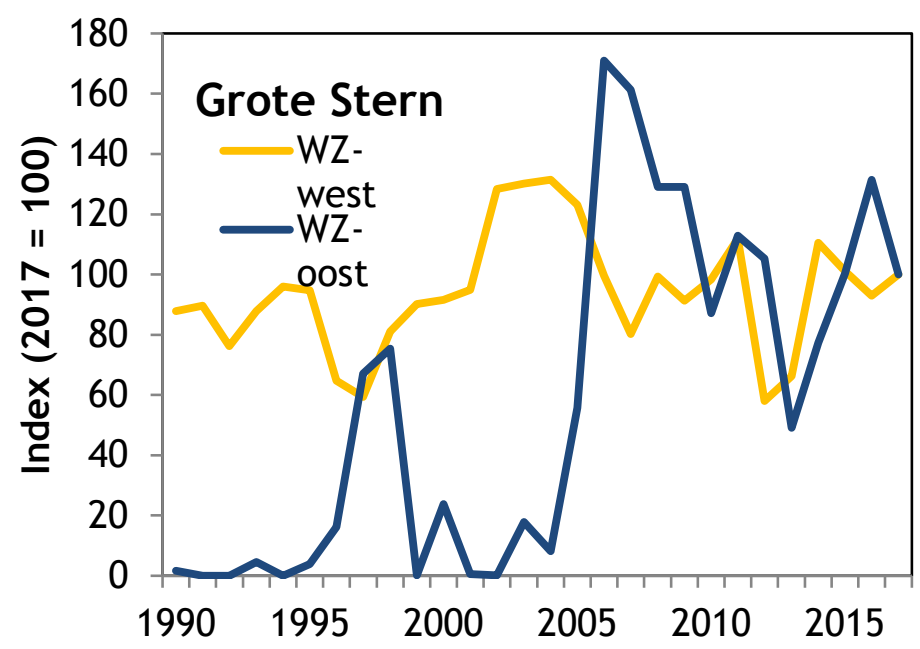

Figuur 3.8. Trend van Grote Stern als broedvogel in de Waddenzee (index), gesplitst naar Westelijke Waddenzee (west van wantij Terschelling) en oostelijke Waddenzee (tot Eemshaven). Gegevens broedvogelmeetnet Sovon/CBS. [Trends in breeding Sandwich Terns (expressed as index) in the western and eastern Wadden Sea.]

\subsection{Visdief Sterna hirundo - Common Tern}

Visdieven namen in de Waddenzee sinds 1990 met gemiddeld 4\% per jaar af, en die ontwikkeling onderscheidt zich bijna niet tussen de westelijke en de oostelijke Waddenzee (figuur 3.9). Duidelijk positiever is de trend in de Eems-Dollard regio, waar kolonies zich concentreren op het Eemshaventerrein, in het havengebied van Delfzijl en op de Punt van Reide bij de Dollard.

Broedsucces-gegevens werden verspreid over de Waddenzee verzameld, vooral in de kuikenfase. Het nestsucces was hoog in de door een elektrisch raster beschermde kolonie bij Oterdum in het havengebied van Delfzijl $(82,5 \%)$, terwijl in een onbeschermde kolonie elders in het havengebied $(5,0 \%)$ en op de Vliehors op Vlieland $(12,4 \%)$ de meeste nesten mislukten. Grote verschillen deden zich ook voor bij het broedsucces. In de meeste kolonies kwamen geen of vrijwel geen jongen groot (Ameland, Griend, Eemshaven, Schermpier haven Delfzijl, Wagejot en Ottersaat op Texel). Alleen de kolonie bij Oterdum, die reeds in de nestfase succesvol was, was goed voor 0,59 jong per paar. Op Vlieland mislukte één kolonie op de Vliehors geheel, maar kwamen in een andere kolonie 0,22 jong per paar groot. Mislukkingsoorzaken waren divers. Hoge vloeden speelden Visdief op Ameland en op 
de Vliehors parten (zomerstorm begin juni), in andere kolonies werd predatie als hoofdoorzaak genoemd. De broedresultaten zijn voor de Waddenzee als geheel te laag voor een stabiele populatie, vergelijkbaar met voorgaande jaren. Het voorbeeld van de kolonie bij Oterdum in het Havengebied van Delfzijl laat echter zien dat met predatie-werende maatregelen zowel een hoog nestsucces als een redelijk broedsucces tot de mogelijkheden behoort.

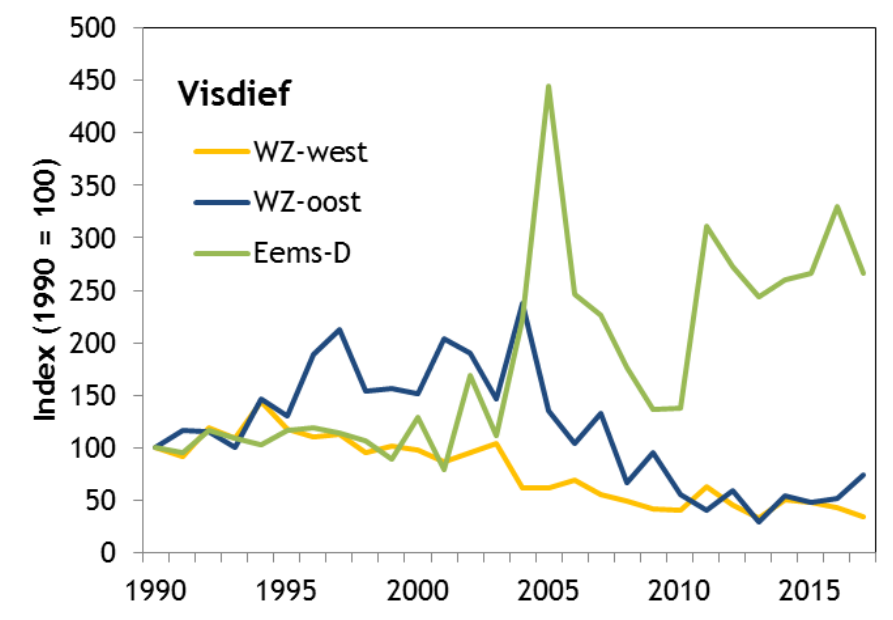

Figuur 3.9. Trends van Visdief als broedvogel in de Waddenzee (index), gesplitst naar Westelijke Waddenzee (west van wantij Terschelling), oostelijke Waddenzee (tot Eemshaven) en Eems-Dollard (Eemshaven-Dollard). Gegevens broedvogelmeetnet Sovon/CBS. [Trends in breeding Common Tern (expressed as index) in the western, eastern Wadden Sea and Eems-Dollard estuary.]

\subsection{Noordse Stern Sterna paradisaea - Arctic Tern}

Vrijwel alle Nederlandse Noordse Sterns broeden in de Waddenzee, waar de soort ongeveer de zuidgrens van z'n broedareaal bereikt. In 2017 werden 1018 paar geteld, waarvan 353 paar op Engelsmanplaat. De trend sinds 1990 is afnemend, in de westelijke Waddenzee een fractie sterker dan in de oostelijke Waddenzee (figuur 3.10). Net als bij Visdief contrasteert de ontwikkeling in de EemsDollardregio, waar zich vooral na 2010 een opvallende toename manifesteert. Het gaat hierbij om kolonies in de Eemshaven, het havengebied van Delfzijl en op de Punt van Reide.

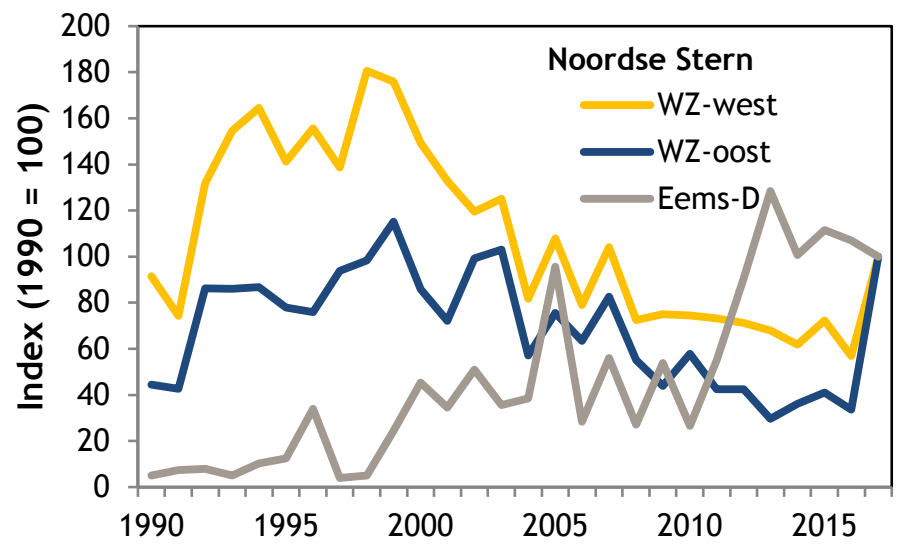

Figuur 3.10. Trends van Noordse Stern als broedvogel in de Waddenzee (index), gesplitst naar Westelijke Waddenzee (west van wantij Terschelling), oostelijke Waddenzee (tot Eemshaven) en Eems-Dollard (Eemshaven-Dollard). Gegevens broedvogelmeetnet Sovon/CBS. [Trends in breeding Arctic Terns (expressed as index) in the western, eastern Wadden Sea and Eems-Dollard estuary.] 
Het nestsucces in een kolonie op de Schermpier van de Haven van Delfzijl en een kolonie op de Vliehors was vergelijkbaar laag (resp. 12,05 en 13,76\%). In geen van beide kolonies werden dan ook veel jongen grootgebracht (resp. 0 en 0,2 jong per paar). Andere kolonies (Griend, Eemshaven, tweede kolonie op de Vliehors) mislukten geheel. Als oorzaken van mislukken werden predatie en hoog water (Vliehors) genoemd. Op Griend werden de meeste nesten verlaten na de storm begin juni (Lutterop \& Kasemier 2018).

Een structureel te laag aantal jonge Noordse Sterns werd ook in voorgaande jaren gesignaleerd. Bij de huidige verspreiding van de kolonies is het echter ook de vraag of de reproductiegegevens representatief zijn. Zo is niet bekend hoeveel jongen er in 2017 uitvlogen in de grote kolonie op Engelsmanplaat en de kolonie op de Friese kust. Voor Engelsmanplaat was wel duidelijk dat door het hoge tij van begin juni het gros van de jongen niet vliegvlug is geworden. 



\section{$4 \quad$ Conclusies en discussie}

In 2017 werden in de Nederlandse Waddenzee voor het $13 e$ achtereenvolgende jaar op gecoördineerde wijze gegevens over het broedsucces van een selectie van kustbroedvogels verzameld. Momenteel gaat het om tien verschillende soorten, die zowel in de Nederlandse Waddenzee als in de Duitse en Deense Waddenzee worden gevolgd (TMAP). In 2017 werd in de Nederlandse Waddenzee op 76 broedplaatsen (of kolonies) informatie verzameld over het nestsucces en het uiteindelijke aantal vliegvlugge jongen per paar. Bij het volgen van de nesten of kuikens werden voor zover mogelijk ook de oorzaken van mislukken vastgelegd.

Uit de resultaten van 2017 blijkt dat vrijwel zonder uitzondering (Lepelaar), het broedsucces structureel te laag is voor een stabiele populatie. Vooral Scholekster, Kluut en Noordse Stern doen het slecht, zij het dat van de laatste soort gegevens uit enkele grote kolonies ontbreken. Eider (kleine steekproef, alleen Vlieland), Scholekster, Kluut, Visdief en Noordse Stern blijken vaak al in de nestfase te mislukken. Grote Sterns deden het in 2017 wat beter dan in voorgaande jaren, maar ook bij deze soort mislukte één van de grote kolonies (kwelder Hollum op Ameland) in z'n geheel door predatie door grote meeuwen. Terugkerende oorzaken van mislukken zijn predatie en hoge vloeden; bij sommige soorten spelen waarschijnlijk ook voedselproblemen een rol. De aard van de gegevens laat vaak niet toe om de mate van mislukken door de verschillende oorzaken heel precies te kwantificeren. Toepassing van predatie-werende maatregelen in de Haven van Delfzijl (Oterdum) en op de Punt van Reide (beide met elektrisch raster) laten zien dat zowel het nestsucces als het uiteindelijke broedsucces hiervan profiteren (Kokmeeuw, Visdief), maar tegelijk is er ook het voorbeeld van de Klutenplas in Noord-Groningen, waar het raster naar verloop van tijd minder effectief wordt, en predatoren toch het broedseizoen voor Kluut en andere soorten deden mislukken.

Het is dan ook niet verwonderlijk dat de aantallen bij veel soorten kustbroedvogels in de Waddenzee afnemen (o.a. Koffijberg et al. 2015a, Boele et al. 2018), en dat geldt zowel voor de internationale Waddenzee als de Nederlandse Waddenzee afzonderlijk. Veel broedvogels voldoen niet aan de doelstellingen van het internationale Waddenzeeplan, of hun aantallen bevinden zich onder de geformuleerde instandhoudingsdoelstellingen voor Natura 2000 in de Nederlandse Waddenzee. De combinatie van negatieve trends in aantallen broedparen en magere broedresultaten bij een aantal soorten suggereert dat broedsucces een belangrijke verklaring is voor de geconstateerde afnames. Broedsucces kan echter niet los worden gezien van de jaarlijkse overleving (of eventuele immigratie of emigratie).

Van der Jeugd et al. (2014) onderzochten voor alle relevante vogelsoorten in de Waddenzee de populatiedemografie (broedsucces en overleving) en concludeerden dat bij de meeste soorten het (gebrek aan) broedsucces het sturende mechanisme was achter de negatieve aantalsveranderingen. Vooral bij soorten die (deels) van schelpdieren afhankelijk zijn, zoals Eider, Scholekster en Zilvermeeuw, speelde ook de jaarlijkse overleving een belangrijke rol. Hetzelfde geldt voor Lepelaars, waar de overleving net als broedsucces gelimiteerd wordt door dichtheids-afhankelijkheid (Lok 2013).

Bij soorten met een lagere overleving (bijv. Zilvermeeuw) zou het broedsucces verhoogd moeten worden om de jaarlijkse sterfte te compenseren, maar het is maar de vraag of dat ook het geval is. Een periodiek herhaling van de analyse zoals uitgevoerd door Van der Jeugd et al. (2014) zou dan ook een goed instrument zijn om de 'gezondheidstoestand' van de broedvogels in de Waddenzee onder de loep te nemen. Een dergelijke analyse is onlangs uitgevoerd voor het Deltagebied (Schekkerman et al. 2017). Ook daar lijkt het broedsucces van onder andere Kluut, Kokmeeuw, Visdief en Noordse Stern te laag. Bij Kluut was bovendien sprake van een afnemende trend in broedsucces (Schekkerman et al. 2017). Specifiek voor de Waddenzee heeft Programma Rijke Waddenzee verder een actieplan opgesteld om de omstandigheden voor de broedvogels te verbeteren (PRW 2018), en resultaten van het Meetnet Reproductie kunnen worden gebruikt om de resultaten van deze maatregelen te evalueren. 



\section{Literatuur}

Beintema A.J. (1992). Mayfield moet: oefeningen in het berekenen van uitkomstsucces. Limosa 65: 155162.

Boele A., van Bruggen J., Slaterus R., Vergeer J.-W. \& van der Meij T. (2018). Broedvogels in Nederland in 2016. Sovon-monitoringrapport 2018/01. Sovon Vogelonderzoek Nederland, Nijmegen.

Boer P. de (2018). Broedvogels van de Klutenplas in 2017. aantallen en broedsucces. Sovonrapport 2018/41. Sovon Vogelonderzoek Nederland, Nijmegen.

Boer P. de, Oosterbeek K., Koffijberg K., Ens B., Smit C. \& de Jong M. (2007). Broedsucces van kustbroedvogels in de Waddenzee in 2006. SOVON-monitoringrapport 2007/03, IMARES-rapport C036/08. SOVON Vogelonderzoek Nederland/IMARES, Beek-Ubbergen/Den Burg.

Bos D., Kleefstra R., Hoekema F. \& Koffijberg K. (2018). Broedvogel- en ganzenmonitoring op de Dollard in 2017. Nul-monitoring in 2017 i.r.t. de Brede Groene Dijk. A\&W-rapport 2415, Veenwouden.

Camphuysen C.J., Berrevoets C.M., Cremers H.J.W.M., Dekinga A., Dekker R., Ens B.J., van der Have T.M., Kats R.K.H., Kuiken T., Leopold M.F., van der Meer J. \& Piersma T. (2002). Mass mortality of common eiders (Somateria mollissima) in the Dutch Wadden Sea, winter 1999/2000: starvation in a commercially exploited wetland of international importance. Biological Conservation 106: 303-317.

CBS (2013). Kwaliteitsrapportage Netwerk Ecologische Monitoring. CBS, Den Haag.

Engelmoer R. (2018). Ameland-Feugelpolle 2017. Broedvogelinventarisaties en hoogwatertellingen. Rapport in eigen beheer.

Jeugd H.P, van der, Ens B.J., Versluijs M. \& Schekkerman H. (2014). Geïntegreerde monitoring van vogels van de Nederlandse Waddenzee. Vogeltrekstation rapport 2014-01. Vogeltrekstation, Wageningen; CAPSrapport 2014-01; Sovon-rapport 2014/18, Sovon Vogelonderzoek Nederland, Nijmegen.

Kats R.K.H. (2007). Common Eiders Somateria mollissima in the Netherlands: The rise and fall of breeding and wintering populations in relation to the stocks of shellfish. PhD-thesis, Universiteit of Groningen.

Kleunen A. van, Koffijberg K., de Boer P., Nienhuis J., Camphuysen C.J., Schekkerman H., Oosterbeek K., de Jong M., Ens B. \& Smit C. (2010). Broedsucces van kustbroedvogels in de Waddenzee in 2007 en 2008. Sovon-monitoringrapport 2010/04, IMARES-rapport C169/10. Sovon Vogelonderzoek Nederland, Nijmegen, IMARES, Texel \& WOT/Alterra, Wageningen.

Kleunen A. van, de Boer P., Koffijberg K., Oosterbeek K. Nienhuis J., de Jong M.L., Smit C.J. \& van Roomen M. (2012). Broedsucces van kustbroedvogels in de Waddenzee in 2009 en 2010. WOt-werkdocument 346. Wettelijke Onderzoekstaken Natuur \& Milieu, Wageningen.

Koffijberg K. \& Smit C. (2013). Broedsucces van kenmerkende kustbroedvogels in de Waddenzee in mineur. WOt paper 25. Wettelijke Onderzoekstaken Natuur \& Milieu, Wageningen.

Koffijberg K., Schrader S. \& Hennig, V. (2011). TMAP Manual breeding success, 2nd version 2011. Common Wadden Sea Secretariat, Wilhelmshaven.

Koffijberg K., Laursen K., Hälterlein B., Reichert G., Frikke J. \& Soldaat L. (2015a). Progress report trends of breeding birds in the Wadden Sea 1991-2013. Wadden Sea Ecosystem 35. Common Wadden Sea Secretariat, Trilateral Monitoring and Assessment Group, Joint Monitoring Group of Breeding Birds in the Wadden Sea, Wilhelmshaven.

Koffijberg K., de Boer P., Hustings F., van Kleunen A., Oosterbeek K. \& Cremer J. (2015b). Broedsucces van kustbroedvogels in de Waddenzee in 2011-2013. WOt-technical report 51; Sovon-rapport 2015/61; IMARES-rapport C153/15. WOT Natuur \& Milieu, WUR, Wageningen / Sovon Vogelonderzoek Nederland, Nijmegen / IMARES, Den Helder.

Koffijberg K., Cremer J, de Boer, P., Postma J. \& Oosterbeek K. (2016a). Broedsucces van kustbroedvogels in de Waddenzee in 2014. WOt-technical report 78; Sovon-rapport 2016/11; Wageningen Marine Research-rapport C112/16. WOT Natuur \& Milieu, WUR, Wageningen / Sovon Vogelonderzoek Nederland, Nijmegen / Wageningen Marine Research, Den Helder. 
Koffijberg K., Frikke J., Hälterlein B., Reichert G. \& Andretzke H. (2016b). Breeding birds in trouble: a framework for an action plan in the Wadden Sea. CWSS, Wilhelmshaven.

Koffijberg K., Cremer J., de Boer P., Nienhuis J., Schekkerman H.; Oosterbeek K. \& Postma J. (2017) Broedsucces van kustbroedvogels in de Waddenzee. Resultaten 2015-2016 en trends in broedsucces in 2005-2016. WOt-technical report 112; Sovon-rapport 2017/66; Wageningen Marine Research-rapport C100/17. WOT Natuur \& Milieu / Sovon Vogelonderzoek Nederland, Nijmegen / Wageningen Marine Research, Den Helder.

Lok T. (2013). Spoonbills as a model system: a demographic cost-benefit analysis of differential migration. Proefschrift, Rijksuniversiteit Groningen, Groningen.

Lok T., Overdijk O., Horn H. \& Piersma T. (2009). De lepelaarpopulatie van de Wadden. Komt het einde van de groei in zicht? Limosa 82: 149-157.

Lok T., Overdijk O., Tinbergen J.M. \& Piersma T. (2013). Seasonal variation in density dependence in agespecific survival of a long-distance migrant. Ecology 94: 2358-2369.

Lutterop D. \& Kasemir G. (2018). Griend Broedvogels en Bewaking 2017. Rapport Vereniging Natuurmonumenten, 's-Graveland.

Oosterhuis R., Dijksen L.J., Ens B.J., Foppen R., de Jong M., Kats, R.K.H., Koks B.J., van Turnhout C. \& Willems F. (2004). Naar een reproductiemeetnet voor broedvogels in de Waddenzee. Alterra-rapport 944 / SOVON-onderzoeksrapport 2004/03. Alterra/SOVON Vogelonderzoek Nederland, Wageningen/BeekUbbergen.

Oudman T., de Goeij P., Piersma T. \& Lok T. (2017). Colony-breeding Eurasian Spoonbills in The Netherlands: local limits to population growth with expansion into new areas. Ardea 105, doi:10.5253/arde.v105i2.a2.

PRW (2018). Actieplan broedvogels Waddenzee. Programma naar een Rijke Waddenzee, Leeuwarden.

Reneerkens J., Piersma T., Spaans B. (2005). De Waddenzee als kruispunt van vogeltrekwegen. Literatuurstudie naar de kansen en bedreigingen van wadvogels in internationaal perspectief. NIOZreport 2005-4, Texel.

Schekkerman H., Arts F.A., van der Jeugd H., Stienen E.W.M. \& van Roomen M. (2017). Naar een demografische analyse van populaties van karakteristieke vogels in het Deltagebied. Sovon-rapport 2017/58, CAPS-rapport 2017/01. Sovon Vogelonderzoek Nederland/Vogeltrekstation/Delta Project Management/Instituut voor Natuur en Bosonderzoek, Nijmegen.

Spaans B., Leopold M. \& Plomp M. (2018). Bepaling van het aantal nesten en het uitvliegsucces van Grote Sterns op Texel met behulp van een drone. Limosa 91: 30-37.

Thorup O. \& Koffijberg K. (2015). Breeding success in the Wadden Sea in 2009-2012: a review. Wadden Sea Ecosystem 36. Common Wadden Sea Secretariat, Wilhelmshaven.

Turnhout C. van (2008). Nestkaartenproject gaat 14e jaar in. SOVON-Nieuws 21 (1) 11-12.

Willems F., Oosterhuis R., Dijksen L., Kats R. \& Ens B. (2005). Broedsucces van kustbroedvogels in de Waddenzee 2005. SOVON-onderzoeksrapport 2005/07 / Alterra-rapport 1265. SOVON Vogelᄀonderzoek Nederland, Beek-Ubbergen / Alterra, Texel. 


\section{Verantwoording en dankwoord}

Het project Reproductiemeetnet kustbroedvogels is onderdeel van de Wettelijke Onderzoekstaken (WOT) Natuur en Milieu, onderdeel Informatievoorziening Natuur, en wordt uitgevoerd in opdracht van het ministerie van Landbouw, Natuur en Voedselkwaliteit (LNV). Contactpersoon bij LNV voor de projecten die onder de Informatievoorziening Natuur vallen is Bernard Baerends. Contactpersoon bij de WOT Natuur en Milieu, thema Informatievoorziening Natuur, is Anne Schmidt van Wageningen Environmental Research.

Het rapport is binnen Wageningen Marine Research beoordeeld door Sander Glorius. Zijn review heeft geleid tot verbeteringen van het document.

\section{Dankwoord}

Uitvoering van het Meetnet Reproductie in de Waddenzee is alleen mogelijk dankzij de bereidwillige medewerking van de terreinbeheerders en een groot aantal vrijwilligers (zowel gegevensverzameling als logistieke ondersteuning). In 2017 ging het om de volgende personen en organisaties:

\section{Texel:}

Bernard Spaans, Marc Plomp, Cor Smit en Giel Witte $(+)$ (VWG Texel), Dick Schermer, Rob Sier en Jitske Esselaar (allen Staatsbosbeheer), Martin de Jong (Noordkop Groen), Jenny Cremer (WMR), Lieuwe Dijksen (Sovon/VWG Texel), Eric Menkveld (Natuurmonumenten) en Bob Loos (VWG Texel).

\section{Vlieland:}

Peter de Boer (Sovon), Carl Zuhorn (Staatsbosbeheer Regio Noord), Petra de Goeij (Rijksuniversiteit Groningen/NIOZ/Metawad) en Henk-Jan van der Kolk (Nederlands Instituut voor Ecologie).

\section{Ameland:}

Ricus Engelmoer, Jan de Jong, Richard Kiewiet (It Fryske Gea), Johan Krol (Natuurcentrum Ameland), Jeffrey Huizenga (Staatsbosbeheer), Jelle Postma en Kees Oosterbeek (beide Sovon).

\section{Schiermonnikoog:}

Kees Oosterbeek, Romke Kleefstra \& Symen Deuzeman (Sovon), Petra de Goeij (Rijksuniversiteit Groningen/NIOZ/Metawad), Erik Jansen (Natuurmonumenten).

\section{Rottumerplaat:}

Bart Ebbinge, Doortje Ebbinge-Dallmeijer, Nelly van Brederode en Hans Roersma, Sjoerd Dirksen $\left({ }^{\dagger}\right)$, Hella Smit, Ali en Harry Horn - allen vogelwachters Staatsbosbeheer Regio Noord. Jaap Kloosterhuis, Jasper Schut en Dennis Moerkerken (allen Staatsbosbeheer Regio Noord).

\section{Rottumeroog \& Zuiderduin:}

Nico de Vries, Jaap Kloosterhuis, Jasper Schut en Dennis Moerkerken (Staatsbosbeheer Regio Noord).

\section{Griend:}

Date Lutterop \& Giny Kasemir, Erik Jansen (Natuurmonumenten).

\section{Noord-Hollandse kust:}

Roelf Hovinga (Landschap Noord-Holland), Lieuwe Dijksen (Sovon).

\section{Groninger kust en Dollard:}

Derick Hiemstra (Avifauna Groningen), Peter de Boer en Romke Kleefstra (beide Sovon), Arjan Hendriks, Silvan Puijman en Dirk Brul (allen Stichting Het Groninger Landschap), Kees Koffijberg (Avifauna Groningen/Sovon), Allix Brenninkmeijer, Japke van Assen, Leo Bruinzeel en Daan Bos 
(Altenburg \& Wymenga), Zwanette Jager (ZiltWater Advies) en Maarten Loonen (Arctisch Centrum, Rijksuniversiteit Groningen).

De schippers van MS Harder Klaas Kreuijer, Freek-Jan de Wal en Jan Kostwinner (Waddenunit, Ministerie van LNV) willen we hartelijk danken voor de logistiek voor de bewakers van Rottumeroog en Rottumerplaat en de tocht naar De Hond.

Alle terreinbeheerders, Staatsbosbeheer, Natuurmonumenten, Het Noord-Hollands Landschap, It Fryske Gea en Het Groninger Landschap en Groningen Seaports worden bedankt voor het verlenen van toestemming om in hun terreinen gegevens te verzamelen.

Adriaan Gmelig-Meyling en Tom van der Meij (CBS) verzorgden de berekening van de trends in aantallen broedparen in het kader van het Netwerk Ecologische Monitoring. 


\section{Verschenen documenten in de reeks Technical reports van de Wettelijke Onderzoekstaken Natuur}

\& Milieu vanaf 2017

WOt-technical reports zijn verkrijgbaar bij het secretariaat van Unit Wettelijke Onderzoekstaken Natuur \& Milieu te Wageningen. T 0317 - 4854 71; E info.wnm@wur.nl

WOt-technical reports zijn ook te downloaden via de website www.wur.nl/wotnaturenmilieu

88 Mol-Dijkstra, J.P.\& G.J Reinds (2017). Technical documentation of the soil model VSD+; Status A

89 Arets, E.J.M.M., J.W.H van der Kolk, G.M. Hengeveld, J.P. Lesschen, H. Kramer, P.J. Kuikman \& M.J. Schelhaas (2017). Greenhouse gas reporting for the LULUCF sector in the Netherlands. Methodological background, update 2016

90 Bruggen, C. van, A. Bannink, C.M. Groenestein, J.F.M. Huijsmans, H.H. Luesink, S.V. Oude Voshaar, S.M. van der Sluis, G.L. Velthof \& J. Vonk (2017). Emissies naar lucht uit de landbouw in 2014 Berekeningen met het model NEMA

91 Os van, J., M.G.T.M. Bartholomeus, L.J.J. Jeurissen \& C.G. van Reenen (2017). Rekenregels rundvee voor de landbouwtelling. Verantwoording van het gebruik van I\&R gegevens voor de landbouwtelling

92 Haas, W. de, R.J. Fontein \& M. Pleijte (2017). Is eenvoudig beter? Twee essays natuur en landschap in het nieuwe omgevingsbeleid

93 Schuiling, C., A.M. Schmidt, I.J. La Rivière \& R.A. Smidt (2017). Beschermde gebiedenregister; Technische documentatie, Status A.

94 Henkens, R.J.H.G., M.M.P. van Oorschot en J. Ganzevles (2017). Bijdrage van Green Deals aan de beleidsdoelen voor natuur en biodiversiteit

95 Arets, E.J.M.M., J.W.H van der Kolk, G.M. Hengeveld, J.P. Lesschen, H. Kramer, P.J. Kuikman \& M.J. Schelhaas (2017). Greenhouse gas reporting for the LULUCF sector in the Netherlands. Methodological background, update 2017

96 IJsseldijk, L.L., M.J.L. Kik, L. Solé \& A. Gröne (2017). Postmortaal onderzoek van bruinvissen (Phocoena phocoena) uit Nederlandse wateren, 2016.

97 Verburg, R.W., W.H.G.J. Hennen, L.F. Puister, R. Michels \& K. van Duijvendijk (2017). Estimating costs of nature management in the European Union; Exploration modelling for PBL's Nature Outlook

98 Bruggen, C. van, A. Bannink, C.M. Groenestein, J.F.M. Huijsmans, H.H. Luesink, S.V. Oude Voshaar, S.M. van der Sluis, G.L. Velthof \& J. Vonk (2017). Emissies naar lucht uit de landbouw in 2015. Berekeningen met het model NEMA

99 Kuiters, A.T., G.A. de Groot, D.R. Lammertsma H.A.H. Jansman \& J. Bovenschen (2017). Genetische monitoring van de Nederlandse otterpopulatie, Ontwikkeling van populatieomvang en genetische status 2016/2017

100 Adriaanse, P.I. \& W.H.J Beltman (2017) Comparison of pesticide concentrations at drinking water abstraction points in The Netherlands simulated by DROPLET version 1.2 and 1.3.2 model suites
101 Daamen, W.P., A.P.P.M. Clerkx \& M.J. Schelhaas (2017). Veldinstructie Zevende Nederlandse Bosinventarisatie (2017-2021).

102 Boer, T.A. de \& F.L. Langers (2017). Maatschappelijk draagvlak voor natuurbeleid en betrokkenheid bij natuur in 2017

103 Buijs, A.E., B.H.M. Elands \& C.S.A. van Koppen (2017) Vijfentwintig jaar burgerbetrokkenheid in het natuurbeleid. Analyse van beleidsdiscoursen en publiek draagvlak

104 Cremer, J.S.M., S.M.J.M. Brasseur., A. Meijboom, J. Schop \& J.P. Verdaat (2017). Monitoring van gewone en grijze zeehonden in de Nederlandse Waddenzee, 2002-2017

105 Glorius, S.T., A. Meijboom, J.T. van der Wal \& J.S.M. Cremer (2017). Ontwikkeling van enkele mosselbanken in de Nederlandse Waddenzee, situatie 2016

106 Hennekens, S.M., W.A. Ozinga \& J.H.J. Schaminée (2017). BioScore 3 - Plants. Background and preprocessing of distribution data

107 Melman, Th.C.P., M.H.C. van Adrichem, M. Broekmeyer, J. Clement, R. Jochem, H.A.M. Meeuwsen, F.G.W.A. Ottburg, A.G.M. Schotman \& T. Visser (2017). Natuurcombinaties en Europese natuurdoelen; Ontwikkeling van een methode om natuurdoelen te realiseren buiten het Natuurnetwerk Nederland

108 Vries, S. de, W. Nieuwenhuizen \& J.M.J. Farjon (2017) HappyHier: hoe gelukkig is men waar?; Gegevensverzameling en bepaling van de invloed van het type grondgebruik - deel I.

109 Overbeek, M.M.M., E. Smeets \& D. Verhoog (2017) Biobased materialen, circulaire economie en natuurlijk kapitaal.

110 Pouwels, R., G.W.W. Wamelink, M.H.C. van Adrichem, R. Jochem, R.M.A. Wegman en B. de Knegt. (2017). MetaNatuurplanner v4.0 - Status A; Toepassing voor Evaluatie Natuurpact

111 Commissie Deskundigen Meststoffenwet (2017). Advies Mestverwerkingspercentages 2018.

112 Koffijberg K., J.S.M. Cremer, P. de Boer, J. Nienhuis, H. Schekkerman, J. Postma \& K. Oosterbeek (2017) Broedsucces van kustbroedvogels in de Waddenzee. Resultaten 2015-2016 en trends in broedsucces in 2005-2016.

113 Arets, E.J.M.M., J.W.H van der Kolk, G.M. Hengeveld, J.P. Lesschen, H. Kramer, P.J. Kuikman \& M.J. Schelhaas (2018). Greenhouse gas reporting for the LULUCF sector in the Netherlands. Methodological background, update 2018 
114 Bos-Groenendijk, G.I. en C.A.M. van Swaay (2018). Standaard Data Formulieren Natura 2000-gebieden; Aanvullingen vanwege wijzigingen in Natura 2000aanwijzingsbes/uiten

115 Vonk, J. , S.M. van der Sluis, A. Bannink, C. van Bruggen, C.M. Groenestein, J.F.M. Huijsmans, J.W.H. van der Kolk, L.A. Lagerwerf, H.H. Luesink, S.V. Oude Voshaar \& G.L. Velthof (2018.) Methodology for estimating emissions from agriculture in the Netherlands - update 2018. Calculations of $\mathrm{CH} 4$, NH3, N2O, NOX, PM1O, PM2.5 and CO2 with the National Emission Model for Agriculture (NEMA)

116 IJsseldijk, L.L., M.J.L. Kik, \& A. Gröne (2018). Postmortaal onderzoek van bruinvissen (Phocoena phocoena) uit Nederlandse wateren, 2017. Biologische gegevens, gezondheidsstatus en doodsoorzaken.

117 Mattijssen, T.J.M. \& I.J. Terluin (2018). Ecologische citizen science; een weg naar grotere maatschappelijke betrokkenheid bij de natuur?

118 Aalbers, C.B.E.M., D. A. Kamphorst \& F. Langers (2018). Bedrijfs- en burgerinitiatieven in stedelijke natuur. Hun succesfactoren en knelpunten en hoe de lokale overheid ze kan helpen slagen.

119 Bruggen, C. van, A. Bannink, C.M. Groenestein, J.F.M. Huijsmans, L.A. Lagerwerf, H.H. Luesink, S.M. van der Sluis, G.L. Velthof \& J. Vonk (2018). Emissies naar lucht uit de landbouw in 2016. Berekeningen met het model NEMA

120 Sanders, M.E., F. Langers, R.J.H.G. Henkens, J.L.M Donders, R.I. van Dam, T.J.M. Mattijssen \& A.E. Buijs (2018). Maatschappelijke initiatieven voor natuur en biodiversiteit; Een schets van de reikwijdte en ecologische effecten en potenties van maatschappelijke initiatieven voor natuur in feiten en cijfers

121 Farjon, J.M.J., A.L. Gerritsen, J.L.M. Donders, F. Langers \& W. Nieuwenhuizen (2018). Condities voor natuurinclusief handelen. Analyse van vier praktijken van natuurinclusief ondernemen

122 Gerritsen, A.L., D.A. Kamphorst \& W. Nieuwenhuizen (2018). Instrumenten voor maatschappelijke betrokkenheid. Overzicht en analyse van vier cases

123 Vullings, L.A.E., A.E. Buijs, J.L.M. Donders, D.A. Kamphorst, H. Kramer \& S. de Vries (2018). Monitoring van groene burgerinitiatieven; Analyse van de resultaten van een pilot en nulmeting in vier gemeenten

124 Boonstra, F.G., Th.C.P. Melman, W. Nieuwenhuizen \& A. Gerritsen (2018). Aanpak evaluatie stelselvernieuwing agrarisch natuurbeheer; Uitgangspunten en opties voor een beleidsevaluatie

125 Vullings, L.A.E., A.E. Buijs, J.L.M. Donders \& D.A. Kamphorst (2018). Monitoring van groene burgerinitiatieven; Methodiek, indicatoren en ervaring met pilot en nulmeting.
126 Beltman, W.H.J., M.M.S. ter Horst, P.I. Adriaanse \& A. de Jong (2018). Manual for FOCUS_TOXSWA v5.5.3 and for expert use of TOXSWA kernel v3.3; User's Guide version 5

127 Van der Heide, C.M. \& M.M.M. Overbeek (2018). Natuurinclusief handelen en ondernemen. Scopingstudie 'Bedrijven, economie en natuur'

128 Langers, F. (2018). Recreatie in groenblauwe gebieden; Actualisatie van CLO-indicator 1258 (Bezoek aan groenblauwe gebieden) op basis van data van het Continu Vrijetijdsonderzoek uit 2015

129 Glorius, S.T., I.Y.M. Tulp, A. Meijboom, L.J. Bolle and C. Chen (2018). Developments in benthos and fish in gullies in an area closed for human use in the Wadden Sea; 2002-2016

130 Kamphorst, D.A \& T.J.M. Mattijssen (2018). Scopingstudie Vermaatschappelijking van natuur. Een overzicht van onderzoek bij Wageningen Universiteit \& Research voor het Planbureau voor de Leefomgeving en het ministerie van Landbouw, Natuur en Voedselkwaliteit

131 Breman, B.C., T.J.M. Mattijssen \& T.M. Stevens (2018). Natuur 2.0. Het natuurdebat op social media.

132 Vries, S. de \& W. Nieuwenhuizen (2018) HappyHier: hoe gelukkig is men waar?; Gegevensverzameling en bepaling van de invloed van het type grondgebruik, deel II

133 Kistenkas, F.H., W. Nieuwenhuizen, D.A. Kamphorst \& M.E.A. Broekmeyer (2018). Natuur- en landschap in de Omgevingswet.

135 Sanders, M.E. (2018). Voortgang realisatie natuurnetwerk. Technische achtergronden bij de digitale Balans van de Leefomgeving 2018

136 Koffijberg K., J.S.M. Cremer, P. de Boer, J. Nienhuis, K. Oosterbeek \& J. Postma (2018). Broedsucces van kustbroedvogels in de Waddenzee in 2017

137 Egmond, F.M. van, S. van der Veeke, M. Knotters, R.L. Koomans, D. Walvoort, J. Limburg (2018). Mapping soil texture with a gamma-ray spectrometer: comparison between UAV and proximal measurements and traditional sampling; Validation study

139 Berg, F. van den, A. Tiktak, D.W.G. van Kraalingen, J.G. Groenwold \& J.J.T.I. Boesten (2018). User manual for GeoPEARL version 4.4.4.

140 Kuiters, A.T., G.A. de Groot, D.R. Lammertsma, H.A.H. Jansman \& J. Bovenschen (2018). Genetische monitoring van de Nederlandse otterpopulatie; Ontwikkeling van populatieomvang en genetische status 2017/2018 



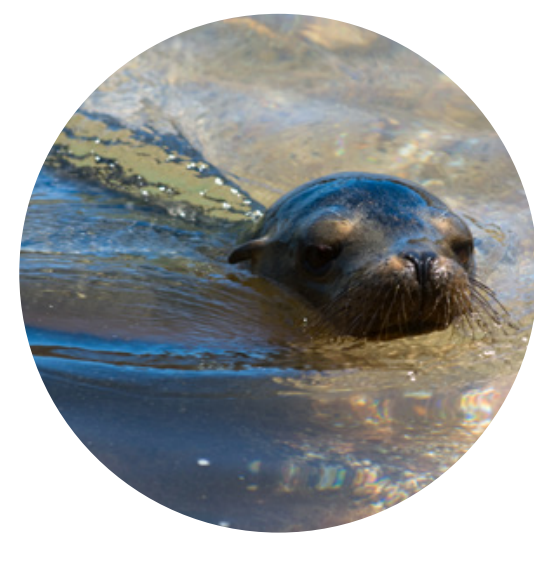

Thema Informatievoorziening Natuur Wettelijke Onderzoekstaken Natuur \& Milieu

Postbus 47

6700 AA Wageningen

T (0317) 485471

E info.wnm@wur.nl

ISSN $2352-2739$

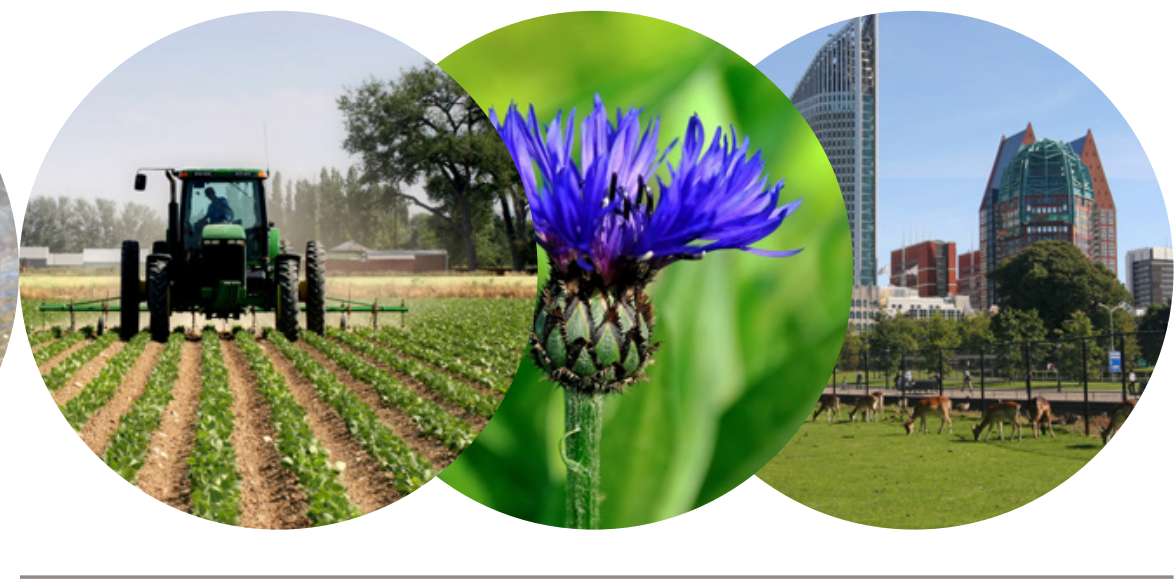

De missie van Wageningen University \& Research is 'To explore the potential of nature to improve the quality of life'. Binnen Wageningen University \& Research bundelen 9 gespecialiseerde onderzoeksinstituten van Stichting Wageningen Research en Wageningen University hun krachten om bij te dragen aan de oplossing van belangrijke vragen in het domein van gezonde voeding en leefomgeving. Met ongeveer 30 vestigingen, 5.000 medewerkers en 10.000 studenten behoort Wageningen University \& Research wereldwijd tot de aansprekende kennisinstellingen binnen haar domein. De integrale benadering van de vraagstukken en de samenwerking tussen verschillende disciplines vormen het hart van de unieke Wageningen aanpak. 